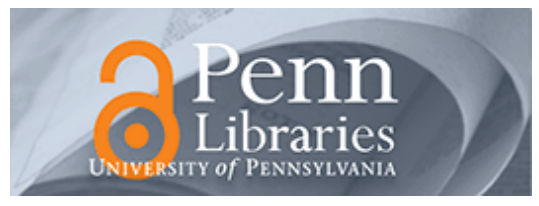

University of Pennsylvania

ScholarlyCommons

Management Papers

Wharton Faculty Research

$1-2016$

\title{
Immigrants and Firm Performance: Effects on Foreign \\ Subsidiaries Versus Foreign Entrepreneurs
}

\author{
Elena Kulchina \\ Duke University \\ Exequiel Hernandez \\ University of Pennsylvania
}

Follow this and additional works at: https://repository.upenn.edu/mgmt_papers

Part of the Management Sciences and Quantitative Methods Commons

\section{Recommended Citation}

Kulchina, E., \& Hernandez, E. (2016). Immigrants and Firm Performance: Effects on Foreign Subsidiaries Versus Foreign Entrepreneurs. Academy of Management Proceedings, http://dx.doi.org/10.5465/

AMBPP.2016.10833abstract

This paper is posted at ScholarlyCommons. https://repository.upenn.edu/mgmt_papers/178

For more information, please contact repository@pobox.upenn.edu. 


\title{
Immigrants and Firm Performance: Effects on Foreign Subsidiaries Versus Foreign Entrepreneurs
}

\begin{abstract}
Prior studies have demonstrated that foreign firms co-locate with immigrants from their home countries, but whether this improves profitability is unclear. We demonstrate that co-national immigrant communities positively affect the performance of foreign firms, and that this effect depends on the type of firm (entrepreneurial venture or MNC subsidiary) and manager (foreign versus local). We found that without an immigrant community, a foreign CEO has a negative effect on the performance of foreign entrepreneurial firms. However, this effect becomes positive as the size of the immigrant community increases because entrepreneurial firms with foreign managers benefit more from their co-national communities than similar firms with local managers. Conversely, MNC subsidiaries derive equal benefits from co-locating with immigrants regardless of their CEO's nationality. This is consistent with our expectation that entrepreneurial firms rely more on local communities than subsidiaries and that CEOs' social networks allow entrepreneurial firms to relate to these communities.
\end{abstract}

\section{Keywords}

foreign CEO, immigrants, multinational corporation

\section{Disciplines}

Management Sciences and Quantitative Methods 


\title{
Immigrants and Firm Performance: Effects on Foreign Subsidiaries versus Foreign Entrepreneurial Firms
}

\author{
Exequiel Hernandez* \\ The Wharton School \\ University of Pennsylvania \\ 2021 SHDH, 3620 Locust Walk \\ Philadelphia, PA 19104 \\ 215-746-1984 \\ exequiel@wharton.upenn.edu \\ Elena Kulchina* \\ Duke University \\ Fuqua School of Business \\ 100 Fuqua Drive \\ Durham, NC 27708, USA \\ 919-660-1093 \\ elena.kulchina@duke.edu
}

\begin{abstract}
Prior studies have demonstrated that foreign firms co-locate with immigrants from their home countries, but whether this improves profitability is unclear. We show that co-national immigrant communities positively affect the performance of foreign firms, but that there is significant heterogeneity in this effect depending on the type of firm (entrepreneurial venture or MNC subsidiary) and manager (immigrant versus local). We find that the immigrant community has a much stronger effect on the profits of foreign entrepreneurial firms when they are managed by an immigrant vs. a native CEO. Conversely, MNC subsidiaries derive equal benefits from co-locating with immigrants regardless of their CEO's nationality. This is consistent with our expectation that entrepreneurial firms have a greater need to be locally embedded and rely more on their local managers' personal networks to derive benefits from local communities, whereas subsidiaries can derive such benefits based on the established organizational resources of the MNC.
\end{abstract}

Keywords: Immigrants, multinational corporation (MNC), immigrant entrepreneur, foreign subsidiary, immigrant CEO, domestic CEO, embeddedness, firm performance

*Authors listed alphabetically and contributed equally.

Acknowledgments: We thank Ashish Arora, Sharon Belenzon, Emilie Feldman, Joanne Oxley, Olav Sorenson, and seminar participants at the London Business School, Northeastern University, University of Miami Global Strategy and Emerging Markets Conference, Strategy Research Forum, and Academy of International Business Meeting for helpful suggestions. We also thank Tansylu Gimadeeva, Malika Kadyrova, Yeo Jin Kim, and Olga Stepanchenko for valuable research assistance. This paper has been awarded the 2016 Temple/AIB Best Paper Award at the Academy of International Business. 
Understanding what drives the performance of foreign firms is a fundamental issue in global strategy. An emerging literature has pointed to the role that immigrants may play in the foreign expansion process of firms from the immigrant community's home country and demonstrated that foreign firms tend to locate in regions with large co-national communities (e.g., Hernandez 2014; Iriyama, Li, and Madhavan 2010). This work has suggested that common nationality provides the basis for social capital by which firm can tap into the supply- or demand-side resources of immigrant communities (e.g., Gould 1994; Hernandez 2014; Kalnins and Chung 2006). We seek to address two unanswered issues in that literature. First, it is unclear whether co-location with home-country immigrants improves foreign firm profitability or whether such co-location is due to inherent differences that make some places attractive to both foreign individuals and foreign firms (e.g., Kulchina 2016a). Some anecdotal evidence even suggests that locating in places with a strong presence of co-national immigrants may hurt performance by limiting firms' chances to grow profitably (Bartlett and O'Connell 1998; Dawar and Chandrasekhar 2009). Our study contributes to this debate by providing systematic evidence that immigrants have a positive effect on firm profitability, and that they do so by both lowering costs and increasing revenues.

Our second contribution is to demonstrate that there is meaningful heterogeneity across firms in whether and how they benefit from the immigrant community. Prior studies on the relationship between immigrants and foreign location choice have focused primarily on the average effect of immigrants across firms. We expect that foreign firms vary in their need to rely on local social networks for their success and that they have differing ability to develop social capital with the local immigrant community. We focus on two groups of firms that differ in this regard: foreign entrepreneurial businesses and subsidiaries of multinational corporations (MNCs). We define a foreign entrepreneurial venture as a firm owned by one or more non-native individuals and an MNC subsidiary as a firm owned by another foreign firm. These two kinds of firms likely benefit from co-national immigrant communities in distinct ways because subsidiaries can rely on the reputation, capabilities, and global network of the MNC while entrepreneurial ventures need to rely more on the social embeddedness and resources of individual entrepreneurs and managers (Dahl and Sorenson 2009; Kulchina 2016b). Moreover, we anticipate that a firm's ability to 
benefit from co-national immigrants also depends on the nationality of its local CEO — an immigrant versus a native of the host country — because it affects the extent to which the firm is able to embed itself within and obtain resources from the immigrant community. Our argument is that the need and ability to relate to the local immigrant community will interact with each other, such that subsidiaries and entrepreneurial firms will benefit differently from immigrants and the magnitude of this difference will depend on the nationality of the CEO.

We tested these ideas on a sample of foreign firms operating in Russia between 2006 and 2011. These firms are distributed across 85 regions, each varying significantly in the size of immigrant populations of different nationalities. Taking advantage of the uniqueness of Russian vs. non-Russian names, we were able to identify whether the CEO of each establishment was an immigrant or a native Russian. To address endogeneity concerns, we exploited two exogenous shocks to the size of local ethnic communities: the inflow of foreign labor to the construction sites of the Asia-Pacific Economic Cooperation (APEC) forum in Vladivostok and of the Olympic Games in Sochi.

We found that immigrants had a significant positive effect on firm's profitability (operating ROA) and verified that both lower costs and higher revenues drove this effect. There was significant heterogeneity across types of firms. Entrepreneurial firms benefited the most from the size of immigrant community if they were managed by a co-national immigrant CEO. The positive impact of the immigrant community on the profits of subsidiaries of MNCs did not depend on the nationality of the local CEO: they benefited from immigrants regardless of whether the CEO was an immigrant or a native Russian. The effects on entrepreneurial firms managed by immigrant CEOs were particularly pronounced for firms operating in trade and services and in regions where Russians have low trust of foreigners or rely more heavily on social networks. These findings are consistent with the notion that, compared to MNC subsidiaries, entrepreneurial firms have a greater need to be socially embedded in a local community and rely more strongly on the social capital of their managers to derive the benefits of co-locating with immigrant communities. 
This study contributes to the literature in various ways. First, it speaks to the central issue in global strategy: how firms can succeed in foreign markets. By demonstrating that immigrants have a positive effect on firm profitability, it addresses the debate of whether foreign firms actually benefit from co-ethnic communities or simply co-locate with them for idiosyncratic reasons (Hernandez 2014; Iriyama et al. 2010). Moreover, our results reveal a significant difference in the impact that immigrants have on MNC subsidiaries compared to foreign entrepreneurial ventures, thereby emphasizing the importance of considering firm heterogeneity in the immigrant-performance relationship. Second, our findings on the role of immigrant CEOs inform a rapidly growing literature on managing multinational ventures and the costs and advantages of having foreign versus domestic managers (Ghemawat and Vantrappen 2015; Kulchina 2016b; Mezias 2002; Sonkova and Karim 2013; Zhou 2014).

Our findings also speak to a set of broader issues. We bring together the literatures on MNCs and foreign entrepreneurs (which have previously been developed in parallel) and highlight the distinct mechanisms by which each can benefit from social communities in foreign markets. Our paper further informs research on the social embeddedness of firms. Unlike some studies that equate the social ties of the entrepreneur to the social ties of the firm (e.g., Dahl and Sorenson 2012; Shane and Stuart 2002), our work suggest that the ability of an entrepreneurial venture to benefit from the local community strongly depends not only on who founds the firm, but also on who operates it. In contrast, established firms such as MNCs seem capable of deriving benefits from local communities based on organizational rather than individual factors. Thus our work contributes to the broader research on how different types of firms acquire and benefit from social capital (e.g., Sorenson and Rogan 2014).

\section{Theory and Hypotheses}

The performance of foreign firms has long been a question of scholarly and managerial interest. The literature on this topic is typically rooted in the assumption that foreign entrants suffer from a liability of foreignness - a relative lack of knowledge, influence, or legitimacy compared to domestic incumbents (Hymer 1976; Zaheer 1995). Hence research emphasizes factors that help firms overcome these 
disadvantages as drivers of foreign firm performance. While these factors can take on many forms, they can be categorized as local resources (Harris 1954; Wheeler and Mody 1992), certain capabilities or knowledge unique to the focal firm (Hymer 1976; Kogut and Zander 1993), and unique networks that provide some kind of preferential access to resources or useful knowledge (Johanson and Vahlne 2009). Recently, scholars have taken note of the presence of an immigrant community of the same nationality as the foreign firm as a potentially valuable factor that helps overcome the liability of foreignness by providing access to resources, knowledge, and social networks.

Interest in the relationship between immigration and the international activities of firms began with studies showing that migration increased trade between pairs of countries (Combes, Lafourcade, and Mayer 2005; Gould 1994; Head and Ries 1998; Rauch and Trindade 2002). Subsequent studies found that immigration affects foreign direct investment (FDI) at the country level (Bandelj 2002; Buch, Kleinert, and Toubal 2006; Foad 2012; Leblang 2010). These macroeconomic effects were important precedents for international strategy scholars because firms are the primary vehicles of trade and FDI (UNCTAD 2006). Thus in recent years studies at the firm level have shown that the presence or size of an immigrant community is a significant predictor of foreign location choice for firms from the same home country as the immigrant group (Hernandez 2014; Iriyama et al. 2010). The empirical regularity, in both countryand firm-level studies, is that co-location between immigrants and a firm of the same nationality is common.

The crucial but still unanswered question from a strategic standpoint is whether co-locating with immigrants is beneficial for firm performance. Evidence on performance effects is sparse. Kalnins and Chung (2006) demonstrated that entrepreneurial firms owned by immigrants survived longer when located near firms owned by immigrants of the same ethnicity. Hernandez (2014) showed that subsidiaries of multinationals had higher survival rates when located in states with higher shares of immigrants from the same home country among the total population. Rangan and Sengul (2009) provided evidence that subsidiaries had higher sales in countries where the local population historically originated from an ethnicity similar to the population of the home country, but it is less clear to what extent this 
effect is driven by immigration vs. other historical relationships between home and host country correlated with similarity in ethnic composition. While prior evidence suggests that there may be an association between some aspects of foreign firm performance and the presence of home-country immigrants, such association does not necessarily translate into positive overall firm profitability, nor does it indicate a causal effect of immigrants on firm performance. Immigrant populations are small relative to the native population and may not be the most profitable segment of the market to serve, or the knowledge and other resources they offer may not be relevant for operating in the local environment. Indeed, some anecdotal evidence has suggested that managers are aware of these limitations when considering co-locating with immigrant populations (e.g., Bartlett and O'Connell 1998; Dawar and Chandrasekhar 2009). And since most of the evidence has focused on location choice rather than performance outcomes, it could be that immigrants and firms locate in the same places for spurious reasons.

Conceptual arguments for why immigrants can help firms become more profitable have been made by a variety of scholars. Immigrants can help firms through supply or demand effects. On the supply side, immigrants can enable firms of the same nationality to obtain resources such as labor and capital at lower costs (e.g., Kalnins and Chung 2006; Kulchina 2016b) or transfer valuable knowledge across locations more effectively (Kerr 2008). On the demand side, immigrants may directly be customers of the focal firm or can create demand for the firm's products (or brand) among the native population (Gould 1994). One mechanism underlying both demand and supply effects is access to knowledge - the ability of immigrants to help firms learn about opportunities, resources, and "ways to do things" in the host location. Further, this knowledge (and other resources) is made available through the social networks typical of immigrant communities, which span both the home and the host countries (Levitt 2001). Perhaps most crucial is that access to the resources (broadly defined) offered by an immigrant community tends to be restricted — or at least is given preferentially — to those who share the nationality or ethnicity of the population, such as firms owned by those from the same home country (Hernandez 2014). Common nationality also allows a firm to become socially embedded with the immigrant community and 
derive the benefits of social capital frequently discussed in the literature (Granovetter 1985; Kalnins and Chung 2006). Consistent with these arguments, we predict that:

Hypothesis 1: The size of an immigrant community will have a positive effect on the profitability of firms from the same home country located in the host location.

While establishing an effect of immigrant communities on foreign firm performance is an important step, there is likely to be significant firm heterogeneity behind the relationship. Exploring that heterogeneity can be valuable to better understand the mechanisms by which immigrants benefit firms and the conditions under which those mechanisms are activated. The bulk of the arguments proposing a performance effect, which we just reviewed, build on the notion that co-nationality between the firm and the immigrant community is valuable because it allows the firm to become socially embedded within the community and hence obtain some kind of preferential access to its resources, consumers, or network connections. We thus expect that one of the main sources of firm heterogeneity worth exploring is the focal firm's need and ability to be socially embedded with the immigrant community.

We consider two related factors that drive such need and ability: whether the foreign firm is owned by an MNC or an entrepreneur and whether an immigrant or a native CEO manages the firm. The juxtaposition of these two factors creates four types of firms operating in the foreign location, as illustrated in Figure 1: (A) an MNC subsidiary managed by a native CEO, (B) an entrepreneurial firm managed by a native $\mathrm{CEO},(\mathrm{C})$ an MNC subsidiary managed by an immigrant CEO, and (D) an entrepreneurial firm managed by an immigrant CEO. We explore how the impact of the immigrant community on performance differs for these types of firms. We are using the term "immigrant" broadly: the immigrant CEO could be a permanent resident of the host country or a manager on assignment from the parent firm (e.g., an expatriate). While permanent residents and other types of foreign residents have technically different types of immigration status, we use the term "immigrant CEO" for consistency and to express that the manager is from the same country of origin as the focal firm's owner.

Insert Figure 1 about here 
Firms owned by foreign entrepreneurs, such as an American opening a coffee shop in Russia or a Korean establishing a software development firm in the United States, have grown into a significant phenomenon. Foreign-born individuals now constitute almost a quarter of all entrepreneurs in the U.S., employ almost five million people, and earn over half a billion U.S. dollars in revenue annually (Fiscal Policy Institute 2012). Similar trends are observed in Europe and other regions (e.g., Centre for Entrepreneurs and DueDil 2014; Segreti 2009).

One key difference between foreign subsidiaries and foreign entrepreneurial firms lies in how much they need to be embedded within the local community. Prior literature demonstrates that entrepreneurial firms traditionally rely more strongly on the local community to sell their products as well as to obtain supply-side resources and market information than larger, multi-location organizations (e.g., Dahl and Sorenson 2009; Hallen 2008, Sorenson and Audia 2000; Uzzi 1996). In order to reach these local communities, entrepreneurs take advantage of their personal networks and social capital, regardless of whether they start firms in their home countries or in foreign ones (Dahl and Sorenson 2009; Portes 1987). The need to rely on personal networks is much stronger for entrepreneurs than for subsidiaries of established firms because entrepreneurs usually do not have access to other channels through which they can link to the local community. For instance, they lack the brand name and reputation of an established organization, do not have established marketing and sales channels or the support of a parent firm, and have no corporate financial guarantors in the eyes of suppliers and investors.

These considerations underscore another important distinction between entrepreneurial and large firms: not only do the former rely more heavily on the local community, but the locus of the social capital by which they relate to the community differs. Social capital and networks are often attributed to organizations, which is likely correct in the case of firms with an established history, reputation, or brand. But Sorenson and Rogan (2014) argue that social capital frequently belongs to specific individuals within an organization, and we suggest that this is especially the case for entrepreneurial firms without a known track record (Kalnins and Chung 2006). Since in an entrepreneurial venture the CEO is often personally responsible for many essential firm tasks — such as negotiating with investors, finding suppliers and 
consumers, and hiring employees — the CEO's personal network becomes as important as or more important than that of the entrepreneur. Therefore, the personal connections of the CEO should strongly influence how the firm becomes embedded with the community.

Whereas all entrepreneurial ventures need to become socially embedded within the local community, which subset of the community they embed into may vary. In the case of a foreign entrepreneurial firm, whether the appointed CEO is an immigrant or a native becomes important when considering the extent to which the firm's profits are affected by co-national immigrants. We expect that an immigrant CEO will have stronger ties to the immigrant community from his or her home country, whereas a native $\mathrm{CEO}$ will better relate to a community of local nationals. Indeed, Kulchina (2016b) demonstrates that immigrant managers of entrepreneurial firms are better able to attract cost-efficient coethnic labor than native managers of similar foreign ventures. More broadly, appointing an immigrant manager may bring the advantage of tapping potentially valuable resources from the co-ethnic community, while appointing a native manager may be more useful in reducing the liability of foreignness and getting access to domestic investors, suppliers, or consumers.

The performance outcomes of having each type of manager are likely to depend on the size of the co-national immigrant community in the host location because that determines in what community the entrepreneur must become embedded. In the absence of an immigrant community, a native CEO can be especially helpful to enhance the performance of an entrepreneurial firm because the native will have higher levels of social capital within and knowledge about supply and demand conditions in the host market. An immigrant manager would exacerbate the disadvantages of foreignness in the eyes of the native population because the manager is not embedded within the community and the firm lacks other “organizational” resources such as reputation, branding, or history to overcome the manager's lack of social capital. However, the greater the size of an immigrant community in the host location, the more valuable an immigrant manager's personal network becomes. The immigrant community will be more important to the fate of the firm, serving as the basis to obtain customers, employees, and other resources, 
or simply as a "mediator" between the firm and local buyers and suppliers. This should be manifested in the following empirical observation:

Hypothesis 2: The size of an immigrant community will have a more positive effect on the profitability of co-national entrepreneurial firms if they are managed by an immigrant CEO than if they are managed by a native CEO. [D > C in Figure 1a]

Like foreign entrepreneurial firms, subsidiaries of MNCs face a liability of foreignness that an immigrant community can help ameliorate. In the eyes of the immigrant community, MNCs are well known because of prior interactions in the home country. Immigrants may serve as customers for the MNC, or be employed by it, or simply be aware of the firm. This is particularly likely for MNCs because they tend to be the largest and most visible firms in their home countries. While that recognition exists in the eyes of the co-national immigrant community, it does not always exist in the eyes of the native (host country) population. Hence, immigrants can provide direct benefits as well as be a helpful link between the subsidiary and the local market, as argued by the research we cited in support of Hypothesis 1 .

But as mentioned earlier, subsidiaries have at their disposal means to engage with the local immigrant community that are tied to the reputation and global network of the parent firm instead of the individuals managing the firm. Multinational organizations are frequently able to rely on a globally recognized brand name or quickly establish credibility with local co-ethnic stakeholders by appealing to a long history of successful operations in other markets (Ettenson 1993). Indeed, the theory of the MNC suggests that such intangible assets are frequently the very reason for foreign expansion (Buckley and Casson 1976; Hymer 1976). Further, while local resources or customer markets are important for subsidiaries, these firms are part of a global network of other MNC units that frequently provides them with demand- or supply-related benefits. For example, a subsidiary may obtain a certain raw material available in the host country but not need to sell the resulting product in the local market because its client is another subsidiary of the MNC in a different country (i.e., an export-oriented operation). Alternatively, a subsidiary may still sell goods in the local market but use formal marketing and distribution channels established by the parent firm instead of relying on immigrants. Or the subsidiary may sell in the local 
market but import the product and hire employees from MNC headquarters (i.e., an import-oriented operation).

In short, subsidiaries have a lower social and geographic dependence on the local community compared to entrepreneurial firms. And in the process of relating to the local immigrant community, subsidiaries have lower dependence on the social networks of their top managers than entrepreneurs. These considerations would be consistent with the following two empirical results:

Hypothesis 3: Being managed by an immigrant vs. a native CEO will have a stronger positive effect on the relationship between the size of the immigrant community and profitability for conational entrepreneurial firms than for subsidiaries of multinational firms. [(D - C) > (B - A) in Figure 1a]

Hypothesis 4: The size of an immigrant community will have a more positive effect on the profitability of co-national entrepreneurial firms managed by an immigrant CEO than on the profitability of co-national subsidiaries of multinational firms managed by an immigrant CEO. [D $>$ B in Figure 1a]

Taken together, hypotheses 2 through 4 imply that, among the four combinations of foreign firms in Figure 1a, foreign entrepreneurs with immigrant CEOs should experience the largest benefits from the size of the local co-national immigrant community.

Hypothesis 5: The size of an immigrant community will have the strongest positive effect on the profitability of co-national entrepreneurial firms managed by an immigrant $C E O$ compared to the other three types of firms. [D > A, B, C in Figure 1a]

\section{Data and Variables}

Sample: We empirically tested our ideas on a sample of foreign firms that operated in Russia between 2006 and 2011. The firm-level data came from the Ruslana database owned by Bureau van Dijk (BvD), which provides establishment-level financial and operational data as well as the names of managers and information on each establishment's owners. Ruslana is part of the Amadeus and Orbis databases managed by BvD, which have been extensively used by researchers (e.g., Belenzon, Berkovitz, and Rios 2013; Bloom, Kretschmer, and Van Reenen 2011; Kulchina 2016b). The Russian setting has several characteristics important for our study. First, Russia is a large country with many regions, which vary significantly in terms of immigrant populations. Second, the BvD database provides detailed financial, 
ownership, and top management information on all foreign firms operating in Russia, including subsidiaries of foreign corporations and private businesses founded by foreign entrepreneurs. Finally, the uniqueness of Russian names helps determine whether top managers of foreign firms are Russian or foreign. In a preliminary analysis (not shown, available from the authors on request) we verified that the size of the co-national immigrant community had a positive and significant effect on the location choices of foreign firms in Russia — similar to research conducted in developed market settings (e.g., Hernandez 2014; Iriyama et al. 2010).

Our dataset consists of 23,489 firms with at least 50 percent foreign ownership and at least one year of financial data, and for which we were able to identify whether the CEO was an immigrant or a native Russian for all years with financial data. To construct this sample, we first excluded firms that were operated by a management company $(0.2 \%$ of the initial sample). The remaining firms had individuals as CEOs. For 19 percent of firm-year observations, CEO nationality was listed in the database. For the remaining firm-year observations, we took advantage of the uniqueness of Russian names to identify the immigrant status of the CEO. ${ }^{1}$ We excluded from our identification procedure some countries whose nationals may have names that are similar to typical Russian names, such as Ukraine, Belarus, Latvia, Lithuania, Estonia, Moldova, and Kazakhstan. ${ }^{2}$ We use firms from these countries only when their managers' nationalities are listed in Ruslana.

Of the firms in the final sample, 65 percent are wholly owned foreign firms. Furthermore, 79 percent of the firms are MNC subsidiaries, and 21 percent are owned by foreign entrepreneurs. In line with prior literature, we define an entrepreneurial firm as one that is owned by one or several individuals (Aldrich and Waldinger 1990; Sørensen 2007). In the sample, 17 percent of the firms are operated by an immigrant CEO and 83 percent have a Russian CEO. Immigrant CEOs come from the home countries of

\footnotetext{
${ }^{1}$ Similar approaches, inferring the nationality or foreign ownership from names, have been broadly used in the management literature (e.g., Foley and Kerr, 2013; Kalnins and Chung 2006).

${ }^{2}$ This explains why our final sample has a disproportionally smaller share of firms coming from the former Soviet Union republics. Firms with non-missing CEO data are slightly larger, more profitable, and somewhat older than other firms. However, in most cases the magnitudes of the differences are very small. We also confirm that the main effect of immigrants on firm performance is replicated in a complete sample of firms.
} 
their firms. The shares of foreign and Russian CEOs vary significantly for subsidiaries (11\% and 89\% respectively) and foreign entrepreneurs (42\% and 58\% respectively). In regard to Figure 1, our sample consists of 16,546 MNC subsidiaries with Russian CEOs; 1,957 subsidiaries with immigrant managers; and 2,887 and 2,099 foreign entrepreneurial ventures with Russian and immigrant managers, respectively. The sectoral distribution of the sample is as follows: 37 percent of firms are engaged in services, 36 percent in retail and wholesale trade, 14 percent in manufacturing, 7 percent in construction, and 6 percent in other industries. Firms originate from the following regions: Eastern Europe (33\%), Western Europe (28\%), Asia (12\%), North America (7\%), Newly Independent States (NIS) (6\%), and others $(14 \%)$. The sample is quite heterogeneous in terms of firm age and size: the average firm in the sample is 6 years old and has 118 employees, with entrepreneurial firms being slightly younger (4 years old on average) and smaller (29 employees on average). ${ }^{3}$

Dependent variable: In our analysis, we examine whether the size of a co-ethnic community positively affects firm performance. In line with prior studies (Anderson and Reeb 2003), we use operating return on assets (OROA) as a firm performance measure, calculated by dividing earnings before interest and taxes (EBIT) by the book value of assets. ${ }^{4}$

Independent variables: Our main independent variable, $\ln$ (immigrants), is the natural logarithm of the stock of immigrants from country $\mathrm{j}$ in region $\mathrm{r}$ in year $\mathrm{t}$. Data on immigrants by region came from the Russian Statistical Services and are available for 1997-2011. We took the number of foreigners that entered region $\mathrm{r}$ in year $\mathrm{t}$ as permanent residents and constructed a stock of such immigrants by adding together the numbers from previous years starting in 1997, the first year for which we have immigration data available. Starting with 1997 does not bias our findings since the number of immigrants before 1997 is very small. Russia became open to foreigners only in 1992, after the split of the Soviet Union, and immigration was scarce in the first five years due to unattractive economic conditions and undeveloped immigration laws. We focus on the number of permanent residents for two reasons. First, for our

\footnotetext{
${ }^{3}$ Our results hold when we limit our sample to firms founded after 1991, when Russia became open for the majority of foreign investors, or to firms that entered between 2004 and 2013, closer to our observation window.

${ }^{4}$ The results are robust to using return on assets after interest and tax (ROA) as a measure of profit.
} 
observation window, Russian Statistical Services reported the regional distribution of permanent residents but not of foreign workers. We expect, however, that the locations of permanent residents and foreign workers from the same country are highly correlated (because the majority of permanent residents are working people, not refugees). ${ }^{5}$ Second, if there is any temporary discrepancy between permanent residents and foreign workers, foreign firms will tend to locate near permanent residents because firms are founded with long-term expectations and the permanent resident community is more stable than the population of temporary foreign workers. Permanent residents rarely return home, so the outflow of permanent residents is minimal. There is also much less cross-region migration in Russia than in some other countries, such as the U.S., particularly among immigrants, so that cross-regional migration should not significantly bias our measure.

Russia has 85 regions, which are comparable in size to U.S. states. There is significant variation in the number of immigrants across regions, home countries, and years. In 2006, for example, the total number of immigrants varied from 480 (Nenetsk Autonomous region) to 155,125 (Moscow). ${ }^{6}$ Crossregional variation in the number of immigrants is 2.5 times higher than within-region variation. PostSoviet countries naturally provide a larger number of immigrants, with Kazakhstan and Ukraine being at the top. Among other countries, the largest numbers of immigrants are from Germany, China, and Israel.

The dummy variable entrepreneur equals 1 when a firm is founded by one or more foreign individuals and 0 when it is founded by a foreign company (MNC). The dummy variable immigrant CEO equals 1 when a firm has an immigrant CEO and 0 when it has a Russian CEO.

Control variables: In line with prior studies of foreign firms and of firm performance (Anderson and Reeb 2003; Kulchina 2016a; Villalonga and Amit 2006; Wasserman 2003), we include a range of control variables comprising firm, home-country, and host-region characteristics that may influence the number of immigrants, location choice, and firm performance. These variables are described in greater detail when we introduce specific models of firm performance. Table 1 displays firm-level variable

\footnotetext{
${ }^{5}$ Indeed, in Russia at the national level the number of permanent residents from country $\mathrm{j}$ has a strong positive correlation with the number of foreign workers from the same country.

${ }^{6}$ Our results are robust to taking out larger regions, such as Krasnoyarsk territory and Republic of Sakha-Yakutia.
} 
definitions and descriptive statistics at the firm-year level. Table 2 reports correlation matrices for the key variables from the firm-year panel sample.

Insert Table 1 about here

Insert Table 2 about here

\section{Analyses}

Firm performance and the size of the local immigrant community: As the first step in testing our hypotheses, we assess whether there is a positive relationship between the performance of foreign firms and the number of co-national immigrants in the region. We use an OLS model to estimate the following equation:

$O R O A_{i t}=\beta_{0}+\beta_{1} \operatorname{Ln}(\text { immigrants })_{j r t}+\beta_{2} \operatorname{Ln}(\text { assets })_{i t}+\beta_{3} \operatorname{Ln}(\text { debt })_{i t}+\beta_{4} \operatorname{Ln}(\text { age })_{i t}+$ $\beta_{5}$ Country controls $_{j t}+\beta_{6}$ Region controls $_{r t}+Y_{t}+I_{i}+e_{i t}$,

where $i$ is a firm, $j$ is a home country, $r$ is a region in Russia, $Y_{t}$ is a set of year of observation dummies, $I_{i}$ is a set of industry dummies (at the two-digit level), and $e_{i t}$ is an error term. In the baseline model, we control for the natural logarithms of assets, debt, firm age, and home-country and host-region gross domestic products (GDP) per capita in nominal U.S. dollars. Subsequent models also account for a number of other country and region characteristics and country and region fixed effects. Standard errors are clustered by country-region (clustering by firm, region, or country does not change the findings).

The results of the baseline model in column 1 of Table 3 point to a positive correlation between the performance of foreign firms and the number of co-national immigrants in a region. Increasing the number of immigrants in a region from zero to the sample mean of 1,034 people is associated with a 3.5percentage-point increase in firm OROA (for comparison, mean OROA in our sample is $4 \%)^{7}$ These results remain robust to the inclusion of additional country- and region-level control variables. In Model 2

\footnotetext{
${ }^{7}$ This refers to the sample mean of the raw number of immigrants instead of the logged number. For an increase from zero to the mean of $\ln$ (immigrants) $=4.133$, the increase in OROA would be 2 percentage points. All other continuous variables are held at the sample mean, the year is set to 2006, and the industry code is set to retail trade.
} 
we control for the number of immigrants from other countries in the host region, which is important to validate that co-nationality between the firm and the immigrant group, and not just the presence of any immigrant group, drives access to the resources of the immigrant group. In Model 3, we add country and region dummy variables. In Model 4, we add the following time-variant characteristics: unemployment rate, foreign direct investment (FDI) per capita, and inflation for both the host region and the home country; and crime rate, higher-education graduates per capita, R\&D personnel per capita, capital investment per capita, and average wage for the host region. In Model 5, we use firm fixed effects and estimate the effect of within-firm variation in the number of immigrants. In Model 6, we add the set of time-variant country and region characteristics to the model with firm fixed effects. The coefficient for the number of immigrants is positive and significant in all models.

Insert Table 3 about here

While these findings suggest that foreign firms may benefit from locating in a region with a large co-national immigrant community, it is still difficult to interpret the evidence as causal due to potential omitted variable bias. For example, unobserved regional characteristics may simultaneously attract immigrants and positively affect firm performance.

Exogenous variation in the size of the local immigrant community: To address the endogeneity concern, we would like to examine how firm performance changes when the number of co-national immigrants in the host region exogenously increases. In our analysis, we take advantage of an exogenous shock to the size of the local immigrant communities of certain nationalities in two Russian regions between 2008 and 2011. The shock is based on two major construction projects that attracted a significant amount of foreign labor from certain countries. In the late 2000s and early 2010s, Russia conducted two major construction projects to prepare for two large international events. One was the Asia-Pacific Economic Cooperation (APEC) forum 2012, ${ }^{8}$ held in Vladivostok, Primorsk Territory; the other was the 2014 Olympic Games in Sochi, Krasnodar Territory. To meet the demanding construction schedule, the

${ }^{8}$ See https://en.wikipedia.org/wiki/APEC_Russia_2012 
Russian government lifted quotas on foreign construction workers in the two regions. These projects attracted a large number of foreign construction workers from Uzbekistan, Tajikistan, Turkey, China, North Korea, Armenia, Kyrgyzstan, Ukraine, Belarus, and Serbia. Many of these workers came with their family members, who found jobs in other industries; some workers who started in the construction industry gradually transitioned to other industries. We categorized these ten nations as affected countries relative to all other unaffected countries. ${ }^{9}$

We examine whether the inflow of foreign workers had a positive effect on the performance of co-national firms that had entered the two affected regions before 2008. Our treated group is composed of firms from the affected countries and our control group contains firms from all other countries located in the Primorsk and Krasnodar Territories. We exclude firms in the construction industry because the construction boom may have directly affected their performance. The difference in differences model is presented in equation 2:

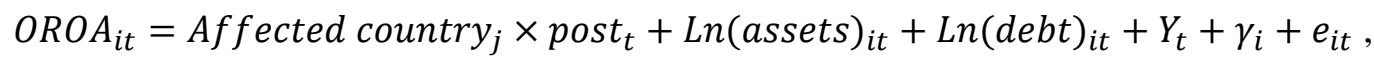

where affected country is one of the 10 countries listed above that supplied foreign workers, post is a dummy variable that equals 1 for years 2008-2011, and $\gamma_{i}$ is a firm fixed effect. Standard errors are clustered by country-region. The main effects of affected country and post time period are captured by the firm fixed effects and the yearly dummy variables, respectively. In line with our theoretical argument, we expect that an inflow of co-national foreign workers had a positive effect on the performance of foreign firms. First, foreign workers and their families could have served as consumers for many co-national firms. Second, workers' family members, and later the workers themselves, could have become employees of non-construction firms. Finally, the suddenly available co-national community could have provided information and networks for foreign businesses.

\footnotetext{
${ }^{9}$ Firms from the affected and unaffected countries have equal pre-treatment trends and are similar on profitability, size, and the level of debt, but are more likely to be owned by entrepreneurs and be managed by immigrant CEOs. Our results remained materially the same when we used a matched sample of firms from the affected countries and the control group. We matched them on observable characteristics using the coarsened exact matching approach (CEM). More details can be found in the robustness checks section.
} 
The findings in Table 4 are in line with our expectations. Firms from affected countries experienced a significant increase in performance during 2008-2011 compared to firms from other countries (see column 1). On average, their OROA increased by 4 percentage points. As a robustness check, we also exclude manufacturing firms, some of which might have supplied materials to the construction industry, and the effect remains materially the same (see column 4). We also make sure that our findings are not driven by firms' anticipation of the construction boom. The first public conversations about the possibility of holding the Olympic Games in Sochi and the APEC forum in Vladivostok started in 2006, and the venues were selected in 2007 by voting during respective committee meetings. We thus check whether our results hold if we limit our sample to firms established in those regions before 2006, the year when investors and managers could first become aware of the possibility and adjust their location choices accordingly. The results remain materially the same (see column 5).

Insert Table 4 about here

Heterogeneity by firm and CEO type: Hypothesis 2 predicts that the size of the co-national immigrant community will have a stronger positive effect on the profitability of entrepreneurial firms when they are managed by foreign rather than Russian managers. In column 1 of Table 5, we limit our sample to entrepreneurial firms and find that the impact of the immigrant community has a significantly more positive impact on the profits of entrepreneurial firms when they are managed by immigrant managers than when they are managed by native ones. Interestingly, our findings imply that in the absence of co-national immigrants, foreign entrepreneurial firms with immigrant managers on average underperform similar firms with Russian managers. This suggests that an immigrant manager may become a liability for a foreign entrepreneurial firm when the local community is composed entirely of natives.

Insert Table 5 about here 
Hypothesis 3 predicts that the positive moderating effect of an immigrant manager will be less pronounced for a subsidiary. We find an even stronger effect than what the hypothesis suggested: for MNC subsidiaries, the positive main effect of the number of co-national immigrants on OROA in the region does not vary with the type of CEO (see column 2 of Table 5). Also, unlike entrepreneurial firms, MNC subsidiaries with immigrant managers exhibit performance similar to that of subsidiaries with Russian managers even in the absence of a local immigrant community. Taken together, our results in columns 1 and 2 are consistent with hypotheses 2 and 3.

In column 3, we test hypothesis 4 , which predicts that a co-national immigrant community has a stronger positive effect on foreign entrepreneurial ventures with immigrant managers than on MNC subsidiaries with immigrant managers. We limit our sample to firms with immigrant CEOs and find results consistent with our proposition. Conversely, when we restrict our attention to firms with Russian managers in column 4, we find that subsidiaries and entrepreneurial firms benefit equally from the immigrant community. Note that the sign of the coefficient suggests that entrepreneurial ventures with Russian managers may receive a lower impact from immigrants, such that the effect of immigrants on these firms may be close to zero. However, statistically, the difference is not significant at any conventional level; therefore, we consider that immigrants equally affect subsidiaries and entrepreneurial ventures with Russian managers.

In column 5, we use a combined sample of foreign entrepreneurs and subsidiaries to estimate moderating effects on the full sample of firms. The results confirm our findings in columns $1-4$. They also support hypothesis 5 by demonstrating that, among the four types of firms listed in Figure 1, foreign entrepreneurial ventures with immigrant managers experience the greatest benefits from co-locating with immigrant communities from their home countries. The results also suggest that an immigrant community benefits foreign entrepreneurs significantly more than subsidiaries when both kinds of firms hire immigrant CEOs. In column 6, we repeat our exercise after adding firm fixed effects and additional timevariant country and region control variables. The findings remain materially the same. Our findings from Table 5 are summarized in Figure 1b. They can also be visualized by looking at Figure 2, where we plot 
the values of firm OROA for different sizes of immigrant communities using the coefficients from model 5 in Table 5. Control variables are kept at their means. Taken together, our results are consistent with the idea that the positive association between the size of the immigrant community and firm performance is the largest for foreign entrepreneurs with immigrant managers relative to all other similar firms.

\section{Insert Figure 2 about here}

In Table 4, we examine the differential impact of the inflow of foreign workers due to the major construction projects on foreign entrepreneurial firms with immigrant CEOs. Column 2 presents the effect on entrepreneurial ventures with immigrant managers, whereas column 3 demonstrates the impact on all other foreign firms. The results suggest that foreign entrepreneurial businesses with immigrant CEOs received a larger benefit from the exogenous inflow of co-national workers compared to other firms. For a median-size entrepreneurial firm from an affected country with an immigrant CEO, this effect translates into an additional $\$ 4,124$ of annual profit. For a comparable other firm, the increase is $\$ 1,094$ per year.

Impact of the local immigrant community on firm cost and revenue: In this section, we test whether the size of an immigrant community has different impacts on the costs and revenues of foreign firms. This helps provide evidence of whether supply- or demand-side effects are at play in the immigrant-profitability relationship. Prior literature has speculated about the existence of these two effects but not empirically tested them (e.g., Gould, 1994). In Table 6, we examine the impact of the number of co-national immigrants on the firms' cost-to-revenue and revenue-to-asset ratios. On average, foreign firms co-located with a large immigrant community have lower cost-to-revenue and higher revenue-to-asset ratios. ${ }^{10}$ Moreover, the immigrant community has an equal impact on lowering costs for both entrepreneurial firms and subsidiaries. However, immigrants have a significantly larger positive effect on the revenue of entrepreneurial firms with immigrant CEOs. At the same time, immigrant CEOs have a negative impact on the revenue of entrepreneurial firms when a co-ethnic community is absent or very small.

\footnotetext{
${ }^{10}$ The results also hold if we use $\ln ($ revenue) and $\ln (\operatorname{cost})$ as dependent variables in place of ratios.
} 
Overall, our findings point to the fact that immigrant communities help firms - regardless of typeoperate more efficiently by reducing costs and increasing the productivity of assets, but foreign entrepreneurial firms with immigrant CEOs have an even higher increase in the revenue-to-asset ratio when co-locating with a co-national immigrant community. This is consistent with the idea that foreign entrepreneurial ventures with immigrant managers may rely more strongly on the consumption of the coethnic community or on the role of the co-ethnic community in creating access to Russian consumers. The idea of a stronger consumption mechanism is also indirectly supported by the fact that foreign entrepreneurs are less likely to export their products than MNC subsidiaries and, therefore, have to rely more strongly on local consumption. ${ }^{11}$

Insert Table 6 about here

\section{Variation in the need and ability to socially connect with an immigrant community: Our} theoretical section argues that foreign entrepreneurial firms with immigrant managers benefit strongly from the local co-national immigrant community because young firms need to be socially embedded within the local community and being managed by an immigrant CEO endows them with a strong ability to become socially embedded within the immigrant part of this community (but may weaken the ability to relate to the Russian part of it). This implies that the strong positive effect of the immigrant community on foreign entrepreneurial firms with immigrant managers should be even more pronounced when a firm has a particularly strong need to be embedded in the local community or when it is particularly difficult for a foreign firm to become embedded within the native Russian community. This may be the case in several empirically observable situations that allow us to further probe into the mechanisms we propose.

First, we expect that entrepreneurs from former Soviet Union republics—such as Ukraine, Belarus, Kazakhstan, and others - will find it easier to relate to the Russian community relative to all other foreign

\footnotetext{
${ }^{11}$ Entrepreneurs are approximately 5 percent less likely to export their products than subsidiaries.
} 
entrepreneurs. Entrepreneurs from these countries have a more similar culture and background and typically have no or few language barriers.

Second, we anticipate that foreign entrepreneurs will find it more difficult to embed themselves in the Russian community when Russian people exhibit low trust toward foreigners. We measure trust toward foreigners using data from the 2005 wave of the World Values Survey, where individuals were asked how much they trust people of another nationality as captured on a four-point scale: (1) trust completely; (2) trust somewhat; (3) do not trust very much; and (4) do not trust at all. We calculate the share of people who answered (1) or (2) out of the total number of respondents in that region. ${ }^{12}$ Then we split our sample into regions with above-median trust and below-median trust, where the median is 0.37 .

Third, access to a large social community should be more important to the success of a business in regions where people strongly believe that networks and relationships are important for success. We measure the importance of networks by using another question from the 2005 WVS: What does, in the individual's opinion, bring success in life—-hard work or luck and connections? The scale ranges from 1 to 10 , with the "hard work" extreme at 1 and the luck and the "connections" extreme at 10 . We calculate an average score by every region and then once again split our regions at the median value of 5.385.

Finally, firms operating in retail trade and services are more likely to sell their products locally and directly to consumers than firms operating in manufacturing. We expect that retail and service firms would find it more important to be accepted in the local community.

Our results in Table 7 are in line with our theoretical arguments. We observe that, among foreign entrepreneurs, the coefficient for the interaction term ln(immigrants)* immigrant CEO is more positive for non-Soviet firms, for ventures located in regions exhibiting low trust toward foreigners and placing high importance on network connections or luck, and for firms in retail trade and services compared to those in manufacturing. While all differences between coefficients are in the right direction, only the

\footnotetext{
${ }^{12}$ The measure of trust and the measure of networks mentioned below are less refined than other regional measures because the lowest geographic unit of observation in WVS is a federal district (at the time of the survey, Russia had seven federal districts), which may contain several regions. Thus we may have the same measure of trust for several regions if they belong to the same federal district.
} 
differences for trust of foreigners, the importance of networks, and industry type are statistically significant at a conventional level. A lack of statistical significance for the type of country may be due to the artificially small sample of firms from former Soviet countries ${ }^{13}$ and the relatively large variation in "Russianness" within that sample (e.g., Ukrainian culture may be more similar to Russian culture than that of Kyrgyzstan). Table 7 presents results only for the subset of entrepreneurial firms for ease of interpretation. But the findings remain materially the same if we use the full sample (including MNC subsidiaries) and include the three-way interaction term $\ln ($ immigrants)*immigrant $C E O *$ entrepreneur. An interesting pattern in those models is that subsidiaries with immigrant managers do not exhibit the same differences in performance across the four conditions: Soviet vs. non-Soviet, low vs. high trust, low vs. high importance of networks, and retail/services vs. manufacturing. This further validates that the need and ability to relate to the immigrant community applies most strongly to foreign entrepreneurial firms managed by immigrant CEOs.

Insert Table 7 about here

Robustness checks: We make sure that our findings are robust to a number of sample and model modifications. First, our results hold when we control for the number of firms from the same home country located in the region (see column 1 of Table 8), which may be correlated with the size of the immigrant population and firm performance. When we introduce this control variable in our models with the construction project shocks, our results also remain materially the same (results are not reported but are available from the authors on request). Second, we examine whether the impact of the size of a conational community differs for firms where the majority of shares is owned by foreign investors versus firms in which all shares are owned by foreign investors. Column 2 demonstrates no significant difference between majority-owned and wholly owned foreign firms. Third, we confirm that the impact of the immigrant community is consistent across small and large firms. In columns 3 and 4, we split our sample

\footnotetext{
${ }^{13}$ Note that we had to exclude firms from several large former Soviet countries when identifying CEO nationality based on names, as nationals of those countries and Russians may have similar names.
} 
into firms with fewer than 50 employees and those with at least 50 employees yet find no significant difference. Finally, we make sure that our findings are robust to using an alternative measure of the immigrant community. In column 5 we use the share of immigrants among the regional population (Hernandez 2014) and in column 6 the inflow of immigrants as the main independent variables and find a positive association between such measures and firm performance.

Insert Table 8 about here

The findings also hold when we measure firm size as the number of employees instead of assets, when we control for distance between home country and host location, when we drop the most popular Russian region for foreign firms (Moscow), and when we eliminate country-region-year observations with zero immigrants. ${ }^{14}$ Moreover, the findings are robust to the exclusion of home countries that may serve as potential tax heavens, such as the Virgin Islands and Cyprus, as well as to eliminating any single influential home country, such as China, the U.S., Germany, or the U.K. We also confirm that we do not find similar effects if we use immigrants from other countries in place of own-country immigrants. Finally, we check if there is any difference in the main effect of immigrants for firms from the former Soviet Union republics (NIS) and firms from other countries given the historical relationship between NIS countries and Russia. Whereas the coefficient for the NIS firms is slightly smaller, the difference is not significantly different from zero.

Furthermore, one may be concerned that our comparison of foreign entrepreneurial firms and subsidiaries is problematic because these types of firms may be inherently different from each other. To explore this possibility, we repeated our tests on a subsample of entrepreneurial firms and subsidiaries matched on key observables, such as assets, debt, age, year, two-digit industry, region, and home country. ${ }^{15}$ The findings from the matched and main samples are materially the same. We repeat the

\footnotetext{
${ }^{14}$ These and any other unreported results are available from the authors on request.

${ }^{15}$ We use a coarsened exact matching (CEM) method (Blackwell et al. 2009). Entrepreneurial ventures and subsidiaries are matched in the first year they show up in our dataset.
} 
matching exercise for our subsample of affected and unaffected countries in the difference-in-differences model from Table 4. Firms are matched in 2007 based on assets, debt, two-digit industry, and age. The estimation with matched firms demonstrates an even greater effect of an exogenous increase in the number of immigrants in the regions with major construction projects than the one that we observed in the unmatched sample.

When explaining the differential impact of immigrant communities on entrepreneurial firms with foreign versus local managers, we relied on the expectation that these managers relate to different parts of local communities. Alternatively, this effect may be driven by the fact that the type of CEO is correlated with the type of population that firms target with their products: Entrepreneurs may hire immigrant CEOs when they sell products targeted to the immigrant population and employ local CEOs when their products better suit local nationals. However, our empirical evidence suggests that such an explanation is unlikely. First, we observe a distinct impact of CEO type for MNC subsidiaries, whereas if CEOs signaled immigrant-friendly products in entrepreneurial firms, they would also signal such products in subsidiaries. Second, in additional analyses we use two other variables that could proxy for the product type: an indicator of whether a firm imports goods from abroad and the share of foreign ownership. We expect that firms that import goods from abroad are more likely to sell foreign products or products oriented toward a foreign population. Furthermore, if local managers were associated with local products, a similar logic might apply to firms with joint foreign-local ownership. Foreign entrepreneurs would engage local co-founders if they expected to sell products targeted to a local population. Conversely, firms with 100 percent foreign ownership would likely carry products for foreign nationals.

If our findings for immigrant CEOs in entrepreneurial firms were driven by the type of product, we would observe results similar to those using the immigrant CEO indicator when using importing behavior and foreign ownership share as proxies for the product type in place of the immigrant CEO indicator. However, when we tried to replicate our findings for immigrant CEOs using the importing dummy variable and 100 percent foreign ownership indicator, we got very different results (see columns 1 and 3 of Table 9). In columns 2 and 4, we also confirm that our differential results for entrepreneurs with 
immigrant CEOs hold when we include the importing dummy variable and the 100 percent foreign ownership indicator. According to this analysis, it is unlikely that our differential findings for entrepreneurial firms with foreign versus local CEOs are driven solely by the differences in product offerings.

Insert Table 9 about here

\section{Discussion and Conclusion}

Our objective was to assess whether immigrants help improve the profitability of firms from their home countries and to explore firm heterogeneity in that relationship. While prior studies have shown that foreign firms tend to locate close to co-national immigrant communities and suggested that such colocation is beneficial for firms (Hernandez 2014, Iriyama et al. 2010), our paper is one of the first to convincingly demonstrate that such co-location positively affects firm profits. Exploiting exogenous variation in the supply of immigrants within our sample allowed us to address important concerns regarding the causality of the relationship between immigrants and firm success. This alleviates the concern that firms may choose to co-locate with immigrants of the same nationality for reasons unrelated to performance, or even for dysfunctional reasons that may undermine performance (e.g., Kulchina 2016a). Further, the finding that the immigrant community lowers costs and increases revenues provides evidence that both the supply and demand effects suggested in prior work are at play (Gould 1994).

Prior empirical work has studied how immigrants affect firms investing in developed markets, while we study the relationship among foreign firms in emerging markets. One may wonder how our findings may generalize to other institutional settings. We expect that they should hold outside of our sample. First, in our preliminary analysis, we verified that the influence of immigrants on location choice (previously found in developed countries) is also present in Russia, bolstering the generalizability of the results. Second, a significant part of our argument is based on the premise that entrepreneurs heavily rely on social networks within local communities. This phenomenon is not unique to Russia and has been 
reported in many developed countries, including the U.S. (e.g., Sorenson and Audia 2000; Uzzi 1996) and Denmark (Dahl and Sorenson 2009).

Aside from speaking to the literature on immigrants directly, our work also contributes to broader fundamental questions about global strategy, social capital, and how firms benefit from their surrounding community. Understanding the drivers of foreign firm performance is the central question of the global strategy literature. While that work has long been rooted in the liability of foreignness, much of the early work focused on factors internal to the firm — especially proprietary assets or capabilities — that helped firms overcome that liability. The notion that the external social networks and relationships of the firm may also be important has gained attention more recently (Johanson and Vahlne 2009). But our understanding of how foreign firms gain access to and benefit from the surrounding community in their host markets is still limited. Distinguishing between foreign firms owned by entrepreneurs and those owned by MNCs has helped us delve into this issue. Moreover, our findings on the role of immigrant CEOs inform a growing literature on managing multinational ventures, which emphasizes the benefits and costs of having foreign versus domestic managers (e.g., Kulchina 2016b; Mezias 2002; Sonkova and Karim 2013; Zhou 2014). We demonstrate that firms that have a stronger need to rely on the support of the local community (i.e., foreign new ventures) but have few formal means to engage with it need a manager of the same nationality as the community to which they relate. Apart from entrepreneurs, this may also be true, for example, for subsidiaries of small or young parent firms, which have no established reputation and less extensive multinational supply and demand chains.

The findings support our expectation that entrepreneurial ventures tap into the resources of the immigrant community through the social capital of the individuals managing the firm. Indeed, selecting a CEO of a nationality most relevant to the composition of the local community is essential for performance: entrepreneurial firms' profits suffer if they appoint an immigrant CEO in a community composed mainly of natives, but this reverses as the presence of co-national immigrants in the community grows. Several of the additional analyses we conducted suggest that this happens because entrepreneurs rely on the surrounding community for supply and especially demand benefits. For instance, the impact of the immigrant community was particularly strong for entrepreneurial firms managed by immigrant CEOs 
in industries that tend to sell directly to local customers (retail and services), and the revenue-enhancing effect of immigrants was stronger for entrepreneurial firms than for subsidiaries of MNCs. We also found that foreign new ventures managed by immigrant CEOs benefit most from immigrants when the native population exhibits low trust toward foreigners. In contrast, the impact of the co-national immigrant community on the profits of MNC subsidiaries is less sensitive to having a CEO of a specific nationality. This does not mean subsidiaries do not need or benefit from social capital. Rather, the means by which they activate community-based resources are more tied to organizational factors - such as the reputation or assets of the firm - than factors attached to the individuals within the firm. In future work, it would be useful to examine in greater depth the individual mechanisms through which immigrant communities benefit foreign firms, such as access to superior resources, increased demand, and network support and information. It would be helpful to understand the relative importance of these mechanisms for various types of firms and under different market conditions.

Our findings also speak to the issue of organizational social capital. The literature has demonstrated that social relationships are essential for firms' success because they provide superior access to resources and consumers and ensure preferential treatment (Bengtsson and Hsu 2015; Granovetter 1985; Sorenson and Audia 2000; Uzzi 1996). One issue of major concern in the literature today is how firms can acquire such relationships, which are frequently held by individuals rather than directly by business entities (Bidwell and Fernandez-Mateo 2010; Sorenson and Rogan 2014). Our findings demonstrate that firms can do so by leveraging the social relationships of their managers. As mentioned, we also provide evidence that managers' social capital may be more important for entrepreneurs than MNC subsidiaries in foreign markets because the two kinds of firms differ in their strategic needs (e.g., reliance on local customers) and in the means available to activate the resources of the community (e.g., firm reputation, prior interaction in the home market). Unlike some prior studies that equate the social ties of the entrepreneur to the social ties of the firm (e.g., Shane and Stuart 2002; Dahl and Sorenson 2012), our results suggest that the ability of an entrepreneurial venture to benefit from the local community strongly depends not only on who founds the firms, but also on who operates it. Thus the hiring decisions of foreign entrepreneurs are a key strategic issue worth exploring further. 
Our work also relates to the literature on communities, which has tended to emphasize the importance of the headquarters (HQ) community as a driver of firms' choices and performance (Marquis 2003). Studying immigrants suggests that the community surrounding the subunits of firms in foreign markets is important to understand firm performance. The immigrant community is also intriguing for the literature because it can be thought of as an "extension" of the HQ community rather than an entirely different foreign one. It may be interesting for future work to consider how the HQ and host market communities interact to affect firms' choices and performance, as well as how attributes of the immigrant community (e.g., education, cohesion, process of assimilation) affect firms.

A further contribution of the study comes from jointly considering the foreign expansion process of entrepreneurial and non-entrepreneurial firms. While the foreign growth of both types of firms has received attention, research on the two has tended to develop in parallel, with significantly less work on the expansion of entrepreneurial firms. One consideration suggested by our findings is that new ventures tend to rely even more than MNC subsidiaries on social capital and networks, making them even more prone to the "liability of outsidership" (Johanson and Vahlne 2009).

In sum, we provide evidence that the effect of immigrant communities on co-national firm performance is likely to be causal. Further, we delve into the heterogeneity in firms' need and ability to become socially embedded with the immigrant community by distinguishing between the type of owner (subsidiary vs. entrepreneur) and the national identity of the CEO (foreign vs. native). In doing so, we explore the drivers of foreign firm performance, study variation in the mechanisms by which firms activate social capital, and assess how the subunits of firms benefit from their local communities. 


\section{REFERENCES}

Aldrich HE, Waldinger R (1990) Ethnicity and entrepreneurship. Annu. Rev. Sociol. 16: 111-135.

Anderson RC, Reeb DM (2003) Founding-family ownership and firm performance: Evidence from the S\&P 500. J. Finance 58(3): 1301-1328.

Bandelj N (2002) Embedded economies: Social relations as determinants of foreign direct investment in Central and Eastern Europe. Soc. Forces 81(2): 409-444.

Bartlett CA., O’Connell J (1998) Jollibee Foods Corp. (A): International expansion. Harv. Bus. Sch. Case.

Belenzon S, Berkovitz T, Rios LA (2013) Capital markets and firm organization: How financial development shapes European corporate groups. Manag. Sci. 59(6): 1326-1343.

Bengtsson O, Hsu DH (201). Ethnic matching in the U.S. venture capital market. J. Bus. Ventur. 30(2): 338-354.

Bidwell M, Fernandez-Mateo I (2010) Relationship duration and returns to brokerage in the staffing sector. Organ. Sci. 21(6): 1141-1158.

Blackwell M, Iacus S, King G, Porro G (2009) cem: Coarsened exact matching in Stata. Stata J. 9(4): 524.

Bloom N, Kretschmer T, Van Reenen J (2011) Are family-friendly workplace practices a valuable firm resource? Strateg. Manag. J. 32(4): 343-367.

Buch CM, Kleinert J, Toubal F (2006) Where enterprises lead, people follow? Links between migration and FDI in Germany. Eur. Econ. Rev. 50(8): 2017-2036.

Buckley PJ, Casson M (1976) The Future of the Multinational Enterprise (Macmillan, New York).

Centre for Entrepreneurs and DueDil (2014) Migrant Entrepreneurs: Building Our Businesses, Creating Our Jobs. Report.

Combes PP, Lafourcade M, Mayer T (2005) The trade-creating effects of business and social networks: Evidence from France. J. Int. Econ. 66(1): 1-29.

Dahl MS, Sorenson O (2009) The embedded entrepreneur. Eur. Manag. Rev. 6(3): 172-181.

Dahl MS, Sorenson O (2012) Home sweet home: Entrepreneurs' location choices and the performance of their ventures. Manag. Sci. 58(6): 1059-1071.

Dawar N, Chandrasekhar R (2009) Dabur India Ltd._Globalization. Richard Ivey Sch. Bus. Case.

Ettenson R (1993) Brand name and country of origin effects in the emerging market economies of Russia, Poland and Hungary. Int. Mark. Rev. 10(5): 14-36.

Fiscal Policy Institute (2012) Immigrant small business owners: A significant and growing part of the economy. Report. 
Foad H (2012) FDI and immigration: A regional analysis. Ann. Reg. Sci. 49(1): 237-259.

Foley CF, Kerr WR (2013) Ethnic innovation and U.S. multination firm activity. Manag. Sci.59: 15291544.

Ghemawat P, Vantrappen H (2015) How global is your C-suite? MIT Sloan Manag. Rev. 56(4): 73-82.

Gould DM (1994) Immigrant links to the home country: Empirical implications for U.S. bilateral trade flows. Rev. Econ. Stat. 76(2): 302-316.

Granovetter M (1985) Economic action and social structure: A theory of embeddedness. Am. J. Sociol. 91(3): 481-510.

Hallen BL (2008) The causes and consequences of the initial network positions of new organizations: From whom do entrepreneurs receive investments? Adm. Sci. Q. 53(4): 685-718.

Harris CD (1954) The market as a factor in the localization of industry in the United States. Ann. Assoc. Am. Geogr. 44(4): 315-348.

Head K, Ries J (1998) Immigration and trade creation: Econometric evidence from Canada. Can. J. Econ. 31(1): 47-62.

Hernandez E (2014) Finding a home away from home: Effects of immigrants on firms' foreign location choice and performance. Adm. Sci. Q. 59(1): 73-108.

Hymer S (1976) The International Operations of National Firms (MIT Press, Cambridge, MA).

Iriyama A, Li Y, Madhavan R (2010) Spiky globalization of venture capital investments: The influence of prior human networks. Strateg. Entrep. J. 4(2): 128-145.

Johanson J, Vahlne J-E (2009) The Uppsala internationalization process model revisited: From liability of foreignness to liability of outsidership. J. Int. Bus. Stud. 40(9): 1411-1431.

Kalnins A, Chung W (2006) Social capital, geography, and survival: Gujarati immigrant entrepreneurs in the U.S. lodging industry. Manag. Sci. 52(2): 233-247.

Kerr WR (2008) Ethnic scientific communities and international technology diffusion. Rev. Econ. Stat. 90(3): 518-537.

Kogut B, Zander U (1993) Knowledge of the firm and the evolutionary theory of the multinational corporation. J. Int. Bus. Stud. 24(4): 625-645.

Kulchina E (2016a) Personal preferences, entrepreneurs' location choices, and firm performance. Manag. Sci. 62(6): 1814-1829.

Kulchina E (2016b) A path to value creation for foreign entrepreneurs. Strateg. Manag. J. 37(7): 12401262.

Leblang D (2010) Familiarity breeds investment: Diaspora networks and international investment. Am. Polit. Sci. Rev. 104(03): 584-600.

Levitt P. 2001. The Transnational Villagers (U. of California Press, Berkeley, CA). 
Marquis C (2003) The pressure of the past: Network imprinting in intercorporate communities. Adm. Sci. Q. 48(4): 655-689.

Mezias JM (2002) Identifying liabilities of foreignness and strategies to minimize their effects: The case of labor lawsuit judgments in the United States. Strateg. Manag. J. 23(3): 229-244.

Portes A (1987) The social origins of the Cuban enclave economy of Miami. Sociol. Perspect. 30(4): $340-372$.

Rangan S, Sengul M (2009) The influence of macro structure in the international realm: IGO interconnectedness, export dependence, and immigration links in the foreign market performance of transnational firms. Adm. Sci. Q. 54(2): 229-267.

Rauch JE, Trindade V (2002) Ethnic Chinese networks in international trade. Rev. Econ. Stat. 84(1): 116130.

Segreti G (2009) Italy's foreign entrepreneurs show new face of immigration. Financ. Times. August 21: 4.

Shane S, Stuart T (2002) Organizational endowments and the performance of university start-ups. Manag. Sci. 48(1): 154-170.

Sonkova M, Karim S (2013) Managing uncertainty: Executive appointments in foreign subsidiary environments. Work. Pap.

Sørensen JB (2007) Bureaucracy and entrepreneurship: Workplace effects on entrepreneurial entry. Adm. Sci. Q. 52(3): 387-412.

Sorenson O, Audia PG (2000) The social structure of entrepreneurial activity: Geographic concentration of footwear production in the United States, 1940-1989. Am. J. Sociol. 106(2): 424-462.

Sorenson O, Rogan M (2014) (When) Do organizations have social capital? Annu. Rev. Sociol. 40: 261280.

UNCTAD (2006) World Investment Report 2006. New York, United Nations.

Uzzi B (1996) The sources and consequences of embeddedness for the economic performance of organizations: The network effect. Am. Sociol. Rev. 61(4): 674-698.

Villalonga B, Amit R (2006) How do family ownership, control and management affect firm value? J. Financ. Econ. 80(2): 385-417.

Wasserman N (2003) Founder-CEO succession and the paradox of entrepreneurial success. Organ. Sci. 14(2): 149-172.

Wheeler D, Mody A (1992) International investment location decisions: The case of U.S. firms. J. Int. Econ. 33(1-2): 57-76.

Zaheer S (1995) Overcoming the liability of foreignness. Acad. Manage. J. 38(2): 341-363.

Zhou YM (2014) Supervising across borders: The case of multinational hierarchies. Organ. Sci. 26(1): 277-292. 


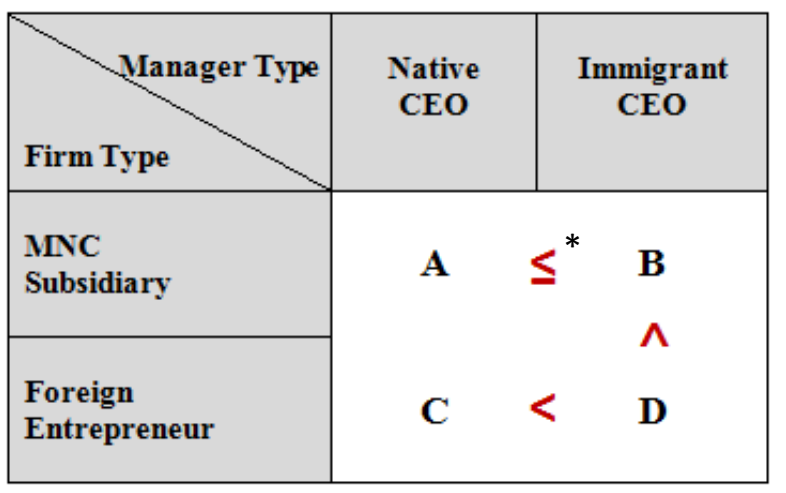

a) Theoretical Predictions

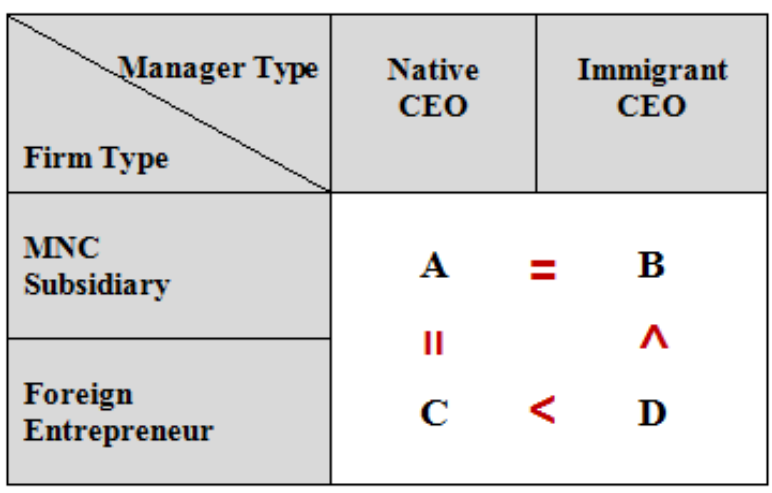

b) Empirical Findings

* Note that we predict that $(\mathrm{D}-\mathrm{C})>(\mathrm{B}-\mathrm{A})$.

Figure 1. The impact of co-national immigrant communities on the performance of foreign firms 


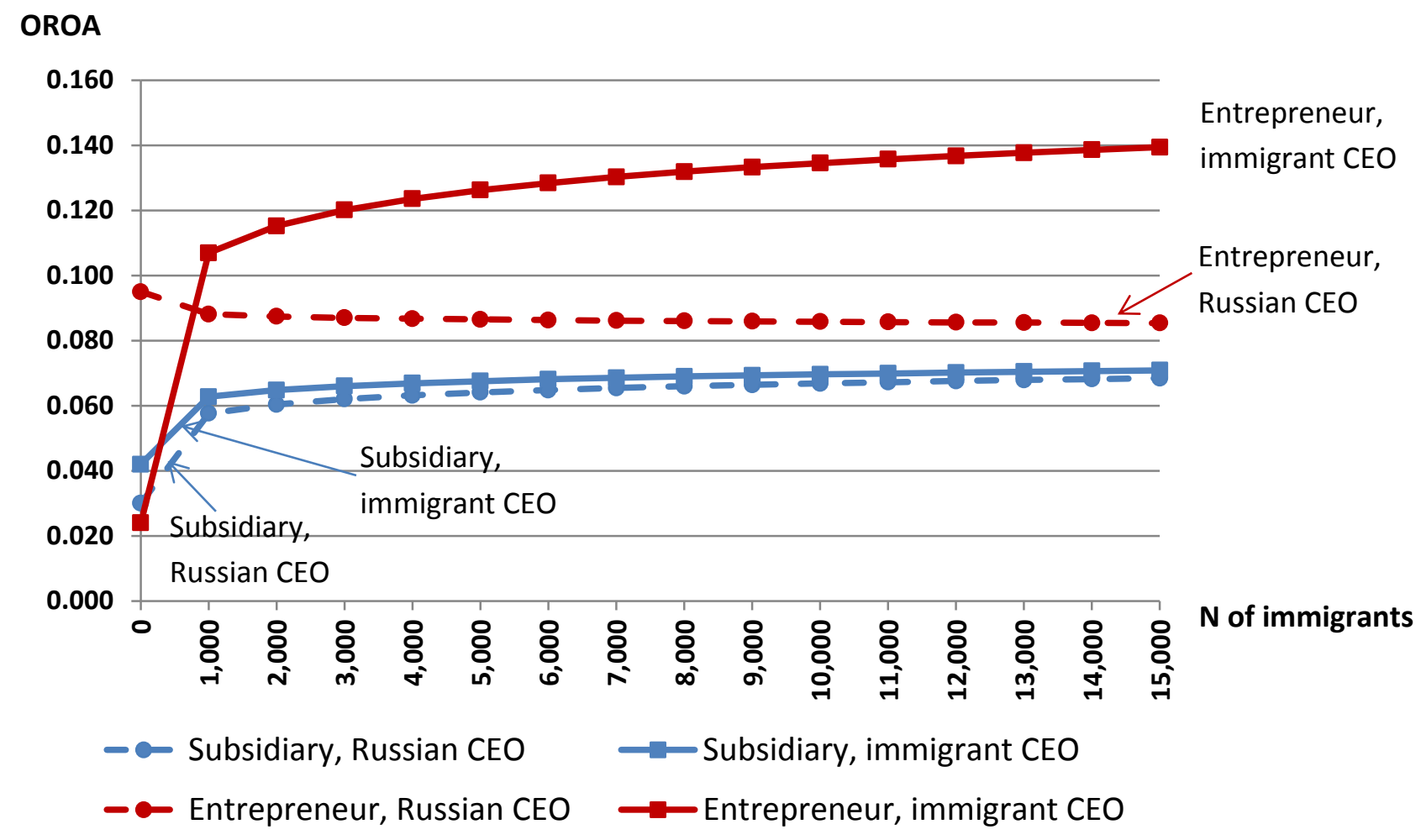

Note: Time-variant control variables are held at their means.

Figure 2. Differential effect of the number of co-national immigrants on foreign entrepreneurial firms and MNC subsidiaries by CEO type 
Table 1. Main Variables ${ }^{\mathrm{a}}$

\begin{tabular}{|c|c|c|c|c|c|c|}
\hline Variable & Description & Mean & Std. Dev. & Min. & Max & $\mathrm{N}$ \\
\hline OROA & $\begin{array}{l}\text { Operating profit (earnings before } \\
\text { interest and taxes) / book value of } \\
\text { assets }\end{array}$ & 0.042 & 0.249 & -1.902 & 1.057 & 57,651 \\
\hline Ln(immigrants) & $\begin{array}{l}\text { Logged number of permanent } \\
\text { residents from the firm's home } \\
\text { country living in the region of the } \\
\text { firm's location in Russia }\end{array}$ & 4.133 & 2.461 & 0 & 11.349 & 57,651 \\
\hline Ln(assets) & Logged book value of assets & 16.700 & 3.247 & 8.006 & 27.499 & 57,651 \\
\hline $\operatorname{Ln}(d e b t)$ & Logged debt & 15.254 & 5.133 & 0 & 26.830 & 57,651 \\
\hline Ln(age) & Logged years since founding & 1.692 & 0.776 & 0 & 5.591 & 57,651 \\
\hline $\begin{array}{l}\text { Ln (country GDP } \\
\text { per capita) }\end{array}$ & $\begin{array}{l}\text { Logged GDP per capita in the } \\
\text { firm's home country (in USD) }\end{array}$ & 9.937 & 1.013 & 5.184 & 12.175 & 57,651 \\
\hline $\begin{array}{l}\mathrm{Ln} \text { (region GDP } \\
\text { per capita) }\end{array}$ & $\begin{array}{l}\text { Logged GDP per capita in the } \\
\text { firm's region of location in Russia } \\
\text { (in USD) }\end{array}$ & 9.463 & 0.701 & 7.288 & 11.805 & 57,651 \\
\hline Entrepreneur & $\begin{array}{l}\text { Dummy variable }=1 \text { for } \\
\text { entrepreneur-owned firms, } 0 \\
\text { otherwise }\end{array}$ & 0.172 & 0.379 & 0 & 1 & 57,651 \\
\hline Immigrant CEO & $\begin{array}{l}\text { Dummy variable }=1 \text { for a firm } \\
\text { with a non-Russian CEO, } 0 \\
\text { otherwise }\end{array}$ & 0.172 & 0.377 & 0 & 1 & 57,651 \\
\hline Cost/revenue & Cost-to-revenue ratio & 0.942 & 0.225 & 0.001 & 1.998 & 40,965 \\
\hline Revenue/assets & Revenue-to-assets ratio & 1.595 & 2.724 & 0 & 25.968 & 57,276 \\
\hline Trust to foreigners & $\begin{array}{l}\text { Share of people who trust } \\
\text { foreigners in the location region }\end{array}$ & 0.380 & 0.043 & 0.31 & 0.45 & 54,900 \\
\hline Networks & $\begin{array}{l}\text { Score of network reliance in the } \\
\text { location region (out of 10) }\end{array}$ & 5.606 & 0.300 & 5.229 & 6.136 & 54,900 \\
\hline Former Soviet & $\begin{array}{l}\text { Countries that are former Soviet } \\
\text { Union republics }\end{array}$ & 0.057 & 0.232 & 0 & 1 & 57,651 \\
\hline
\end{tabular}

a) GDP is measured in USD; all other monetary variables are in Russian rubles. All monetary values are nominal. The inflation effect is captured by the year dummy variables in regression models. We removed outliers by eliminating the top and bottom 1 percent of observations on OROA. This removed observations with OROA above 106 percent and below -191 percent. The cost/revenue ratio does not include firms with zero revenue and outliers. We check that our results hold if we exclude firms with zero revenue from our OROA analysis as well. The revenue/assets ratio also excludes outlier firms and a few firms with missing data. 
Table 2. Main Correlations ${ }^{\mathrm{a}}$

\begin{tabular}{|c|c|c|c|c|c|c|c|c|c|c|}
\hline & Variable & $(1)$ & (2) & (3) & (4) & $(5)$ & $(6)$ & $(7)$ & $(8)$ & (9) \\
\hline (1) & Foreign entrants & 1.000 & & & & & & & & \\
\hline (2) & OROA & $-0.021 * * *$ & 1.000 & & & & & & & \\
\hline (3) & Ln(immigrants) & $0.020 * * *$ & $0.017 * * *$ & 1.000 & & & & & & \\
\hline (4) & Ln(assets) & $0.052 * * *$ & $0.131 * * *$ & $-0.178 * * *$ & 1.000 & & & & & \\
\hline (5) & $\operatorname{Ln}(\mathrm{debt})$ & $-0.010 * *$ & $0.075 * * *$ & $-0.137 * * *$ & $0.804 * * *$ & 1.000 & & & & \\
\hline (6) & Ln(age) & $-0.052 * * *$ & $0.121 * * *$ & $-0.037 * * *$ & $0.349 * * *$ & $0.276^{* * *}$ & 1.000 & & & \\
\hline (7) & $\begin{array}{l}\text { Ln(country GDP } \\
\text { per capita) }\end{array}$ & $-0.010 * *$ & $0.027 * * *$ & $-0.143 * * *$ & $0.277 * * *$ & $0.194 * * *$ & $0.189 * * *$ & 1.000 & & \\
\hline (8) & $\begin{array}{l}\text { Ln } \text { (region GDP } \\
\text { per capita) }\end{array}$ & $0.376 * * *$ & $-0.020 * * *$ & $0.299 * * *$ & -0.001 & $-0.066^{* * *}$ & -0.002 & $0.093 * * *$ & 1.000 & \\
\hline (9) & Entrepreneur & $-0.138 * * *$ & 0.001 & $0.266 * * *$ & $-0.353 * * *$ & $-0.228 * * *$ & $-0.215^{* * *}$ & $-0.466 * * *$ & $-0.093 * * *$ & 1.000 \\
\hline (10) & Immigrant CEO & $-0.133 * * *$ & $0.011 * *$ & $0.185^{* * *}$ & $-0.102 * * *$ & $-0.057 * * *$ & $-0.033 * * *$ & $-0.226 * * *$ & $-0.019 * * *$ & $0.299 * * *$ \\
\hline
\end{tabular}

a) $*, * *$, and $* * *$ denote significance at $10 \%, 5 \%$, and $1 \%$ respectively. 
Table 3. Size of the Immigrant Community and Firm Performance ${ }^{a}$

\begin{tabular}{|c|c|c|c|c|c|c|}
\hline & (1) & (2) & (3) & (4) & (5) & (6) \\
\hline Variables & Baseline & $\begin{array}{l}\text { Controlling } \\
\text { for the stock } \\
\text { of immigrants } \\
\text { from other } \\
\text { countries }\end{array}$ & $\begin{array}{l}\text { Country and } \\
\text { region } \\
\text { dummies }\end{array}$ & $\begin{array}{l}\text { Time- } \\
\text { variant } \\
\text { controls }\end{array}$ & $\begin{array}{l}\text { Firm fixed } \\
\text { effects }\end{array}$ & $\begin{array}{l}\text { Firm fixed } \\
\text { effects and } \\
\text { time-variant } \\
\text { controls }\end{array}$ \\
\hline Dependent variable & OROA & OROA & OROA & OROA & OROA & OROA \\
\hline Model & OLS & OLS & OLS & OLS & OLS & OLS \\
\hline Ln(immigrants) & $\begin{array}{l}\mathbf{0 . 0 0 5 * * *} \\
(\mathbf{0 . 0 0 1 )}\end{array}$ & $\begin{array}{l}\mathbf{0 . 0 0 5 * * *} \\
(\mathbf{0 . 0 0 1 )}\end{array}$ & $\begin{array}{l}\text { 0.004** } \\
(\mathbf{0 . 0 0 2})\end{array}$ & $\begin{array}{l}\mathbf{0 . 0 0 5 * * *} \\
(\mathbf{0 . 0 0 1 )}\end{array}$ & $\begin{array}{l}\text { 0.015** } \\
(\mathbf{0 . 0 0 6 )}\end{array}$ & $\begin{array}{l}\text { 0.013** } \\
(0.006)\end{array}$ \\
\hline Ln(asset) & $\begin{array}{l}0.016 * * * \\
(0.002)\end{array}$ & $\begin{array}{l}0.016 * * * \\
(0.002)\end{array}$ & $\begin{array}{l}0.017 * * * \\
(0.002)\end{array}$ & $\begin{array}{l}0.017 * * * \\
(0.002)\end{array}$ & $\begin{array}{l}0.029 * * * \\
(0.004)\end{array}$ & $\begin{array}{l}0.031 * * * \\
(0.005)\end{array}$ \\
\hline $\operatorname{Ln}($ debt $)$ & $\begin{array}{l}-0.005^{* * *} \\
(0.001)\end{array}$ & $\begin{array}{l}-0.005 * * * \\
(0.001)\end{array}$ & $\begin{array}{l}-0.006 * * * \\
(0.001)\end{array}$ & $\begin{array}{l}-0.006 * * * \\
(0.001)\end{array}$ & $\begin{array}{l}-0.007 * * * \\
(0.002)\end{array}$ & $\begin{array}{l}-0.007 * * * \\
(0.002)\end{array}$ \\
\hline Ln(age) & $\begin{array}{l}0.027 * * * \\
(0.003)\end{array}$ & $\begin{array}{l}0.027 * * * \\
(0.003)\end{array}$ & $\begin{array}{l}0.029 * * * \\
(0.002)\end{array}$ & $\begin{array}{l}0.028 * * * \\
(0.003)\end{array}$ & & \\
\hline $\begin{array}{l}\text { Ln(country GDP per } \\
\text { capita) }\end{array}$ & $\begin{array}{l}-0.004 * \\
(0.002)\end{array}$ & $\begin{array}{l}-0.003 \\
(0.002)\end{array}$ & $\begin{array}{l}0.021 \\
(0.014)\end{array}$ & $\begin{array}{l}-0.004 * \\
(0.003)\end{array}$ & $\begin{array}{l}0.021 \\
(0.014)\end{array}$ & $\begin{array}{l}0.020 \\
(0.016)\end{array}$ \\
\hline $\begin{array}{l}\text { Ln(region GDP per } \\
\text { capita) }\end{array}$ & $\begin{array}{l}-0.017 * * * \\
(0.004)\end{array}$ & $\begin{array}{l}-0.009 * * \\
(0.004)\end{array}$ & $\begin{array}{l}0.015 \\
(0.023)\end{array}$ & $\begin{array}{l}-0.013 \\
(0.011)\end{array}$ & $\begin{array}{l}0.001 \\
(0.020)\end{array}$ & $\begin{array}{l}-0.009 \\
(0.026)\end{array}$ \\
\hline Ln(other immigrants) & & $\begin{array}{l}-0.011 * * * \\
(0.003)\end{array}$ & & & & \\
\hline $\begin{array}{l}\text { Home-country and host- } \\
\text { region time-variant } \\
\text { control variables }\end{array}$ & & & & Yes & & Yes \\
\hline Constant & $\begin{array}{l}-0.021 \\
(0.063)\end{array}$ & $\begin{array}{l}0.021 \\
(0.064)\end{array}$ & $\begin{array}{l}-0.579 \\
(421.491)\end{array}$ & $\begin{array}{l}-0.256^{*} \\
(0.133)\end{array}$ & $\begin{array}{l}-0.613 * * * \\
(0.236)\end{array}$ & $\begin{array}{l}-1.202 * * * \\
(0.365)\end{array}$ \\
\hline Year dummies & Yes & Yes & Yes & Yes & Yes & Yes \\
\hline Industry dummies & Yes & Yes & Yes & Yes & & \\
\hline Country dummies & & & Yes & & & \\
\hline Region dummies & & & Yes & & & \\
\hline $\mathrm{R}^{2} /$ within $\mathrm{R}^{2}$ & 0.040 & 0.041 & 0.053 & 0.042 & 0.015 & 0.016 \\
\hline $\mathrm{N}$ & 57,651 & 57,651 & 57,651 & 55,465 & 57,651 & 55,465 \\
\hline
\end{tabular}

a) Standard errors are clustered on country-region. *,**, and *** denote significance at $10 \%, 5 \%$, and $1 \%$ respectively.

b) Home-country and host-region control variables in column 4 include country unemployment rate, country inflation, $\ln$ (country FDI per capita), $\ln$ (region crime), region unemployment rate, region inflation, $\ln$ (region FDI per capita), region higher-education graduates per capita, region R\&D personnel per capita, region capital investment per capita, and $\ln$ (region average wage). All variables are measured in year $\mathrm{t}$.

Sample and notes: Variation in sample size across specifications is due to differences in data availability for control variables. 
Table 4. Exogenous Increase in the Number of Immigrants in Regions with Major Construction Projects During 2008-2011

\begin{tabular}{|c|c|c|c|c|c|}
\hline & (1) & (2) & (3) & (4) & (5) \\
\hline Variables & All firms & $\begin{array}{l}\text { Entrepreneurs } \\
\text { with } \\
\text { immigrant } \\
\text { CEOs }\end{array}$ & All other firms & $\begin{array}{l}\text { Excluding } \\
\text { manufacturing } \\
\text { firms }\end{array}$ & $\begin{array}{l}\text { Firms founded } \\
\text { before } 2006\end{array}$ \\
\hline Dependent variable & OROA & OROA & OROA & OROA & OROA \\
\hline Model & OLS DD & OLS DD & OLS DD & OLS DD & OLS DD \\
\hline Affected country*post & $\begin{array}{l}0.040 * * \\
(0.018)\end{array}$ & $\begin{array}{l}0.245 * * * \\
(0.065)\end{array}$ & $\begin{array}{l}0.065^{*} \\
(0.036)\end{array}$ & $\begin{array}{l}0.045^{*} \\
(0.024)\end{array}$ & $\begin{array}{l}0.065 * * * \\
(0.022)\end{array}$ \\
\hline Ln(assets) & $\begin{array}{l}0.060 * * * \\
(0.014)\end{array}$ & $\begin{array}{l}0.035 \\
(0.028)\end{array}$ & $\begin{array}{l}0.069 * * * \\
(0.014)\end{array}$ & $\begin{array}{l}0.056 * * * \\
(0.014)\end{array}$ & $\begin{array}{l}0.075 * * * \\
(0.015)\end{array}$ \\
\hline $\operatorname{Ln}($ debt $)$ & $\begin{array}{l}-0.022 * * * \\
(0.007)\end{array}$ & $\begin{array}{l}-0.019 \\
(0.020)\end{array}$ & $\begin{array}{l}-0.025 * * * \\
(0.006)\end{array}$ & $\begin{array}{l}-0.021 * * * \\
(0.007)\end{array}$ & $\begin{array}{l}-0.027 * * * \\
(0.007)\end{array}$ \\
\hline Constant & $\begin{array}{l}-0.565 * * * \\
(0.160)\end{array}$ & $\begin{array}{l}-0.260 \\
(0.153)\end{array}$ & $\begin{array}{l}-0.738 * * * \\
(0.237)\end{array}$ & $\begin{array}{l}-0.538 * * * \\
(0.149)\end{array}$ & $\begin{array}{l}-0.762 * * * \\
(0.234)\end{array}$ \\
\hline Year dummies & Yes & Yes & Yes & Yes & Yes \\
\hline Firm f.e. & Yes & Yes & Yes & Yes & Yes \\
\hline Within $\mathrm{R}^{2}$ & 0.043 & 0.103 & 0.052 & 0.039 & 0.056 \\
\hline $\mathrm{N}$ & 1,899 & 411 & 1,488 & 1,541 & 1,601 \\
\hline
\end{tabular}

a) Standard errors are clustered on country-region. *,**, and *** denote significance at $10 \%, 5 \%$, and $1 \%$ respectively.

Sample: All models exclude the construction industry. Model 2 includes entrepreneurial firms with immigrant CEOs only. Model 3 includes all other firms. Model 4 excludes manufacturing firms. Model 5 is limited to firms founded before 2006, the year of the first conversations about holding the Olympic Games in Sochi and the APEC meeting in Vladivostok. 
Table 5. Subsidiaries and Foreign Entrepreneurs ${ }^{\mathrm{a}}$

\begin{tabular}{|c|c|c|c|c|c|c|}
\hline & (1) & (2) & (3) & (4) & (5) & (6) \\
\hline Variables & Entrepreneurs & Subsidiaries & $\begin{array}{l}\text { Immigrant } \\
\text { CEOs }\end{array}$ & $\begin{array}{l}\text { Russian } \\
\text { CEOs }\end{array}$ & Interaction & $\begin{array}{l}\text { With firm } \\
\text { fixed effects }\end{array}$ \\
\hline Dependent variable & OROA & OROA & OROA & OROA & OROA & OROA \\
\hline Model & OLS & OLS & OLS & OLS & OLS & OLS \\
\hline Ln(immigrants) & $\begin{array}{l}-0.002 \\
(0.003)\end{array}$ & $\begin{array}{l}0.003 * * * \\
(0.001)\end{array}$ & $\begin{array}{l}0.003^{*} \\
(0.002)\end{array}$ & $\begin{array}{l}0.004 * * * \\
(0.001)\end{array}$ & $\begin{array}{l}0.004 * * * \\
(0.001)\end{array}$ & $\begin{array}{l}0.011 * \\
(0.006)\end{array}$ \\
\hline $\begin{array}{l}\text { Ln(immigrants)* } \\
\text { immigrant CEO }\end{array}$ & $\begin{array}{l}0.012 * * * \\
(0.005)\end{array}$ & $\begin{array}{l}-0.001 \\
(0.002)\end{array}$ & & & $\begin{array}{l}-0.001 \\
(0.002)\end{array}$ & $\begin{array}{l}-0.002 \\
(0.003)\end{array}$ \\
\hline $\begin{array}{l}\text { Ln(immigrants)* } \\
\text { entrepreneur } \\
\text { Entrepreneur* } \\
\text { immigrant CEO }\end{array}$ & & & $\begin{array}{l}0.009 * * \\
(\mathbf{0 . 0 0 4 )}\end{array}$ & $\begin{array}{l}-0.005 \\
(0.004)\end{array}$ & $\begin{array}{l}-0.005 \\
(0.004) \\
-0.083 * * \\
(0.032)\end{array}$ & $\begin{array}{l}0.013 \\
(0.019) \\
-0.088^{*} \\
(0.047)\end{array}$ \\
\hline $\begin{array}{l}\text { Ln(immigrants)* } \\
\text { entrepreneur* }^{*} \\
\text { immigrant CEO }\end{array}$ & & & & & $\begin{array}{l}\mathbf{0 . 0 1 4} * * * \\
(\mathbf{0 . 0 0 5})\end{array}$ & $\begin{array}{l}0.012 * \\
(0.007)\end{array}$ \\
\hline Immigrant CEO & $\begin{array}{l}-0.073 * * \\
(0.028)\end{array}$ & $\begin{array}{l}0.010 \\
(0.010)\end{array}$ & & & $\begin{array}{l}0.012 \\
(0.010)\end{array}$ & $\begin{array}{l}0.023 \\
(0.018)\end{array}$ \\
\hline Entrepreneur & & & $\begin{array}{l}-0.009 \\
(0.025)\end{array}$ & $\begin{array}{l}0.063 * * * \\
(0.022)\end{array}$ & $\begin{array}{l}0.065 * * * \\
(0.022)\end{array}$ & \\
\hline Ln(assets) & $\begin{array}{l}0.033 * * * \\
(0.004)\end{array}$ & $\begin{array}{l}0.015 * * * \\
(0.001)\end{array}$ & $\begin{array}{l}0.031 * * * \\
(0.004)\end{array}$ & $\begin{array}{l}0.015 * * * \\
(0.001)\end{array}$ & $\begin{array}{l}0.017 * * * \\
(0.002)\end{array}$ & $\begin{array}{l}0.031 * * * \\
(0.005)\end{array}$ \\
\hline $\operatorname{Ln}($ debt $)$ & $\begin{array}{l}-0.014 * * * \\
(0.002)\end{array}$ & $\begin{array}{l}-0.004 * * * \\
(0.001)\end{array}$ & $\begin{array}{l}-0.013 * * * \\
(0.002)\end{array}$ & $\begin{array}{l}-0.004 * * * \\
(0.001)\end{array}$ & $\begin{array}{l}-0.005^{* * * *} \\
(0.001)\end{array}$ & $\begin{array}{l}-0.007 * * * \\
(0.002)\end{array}$ \\
\hline Ln(age) & $\begin{array}{l}0.011 * * \\
(0.005)\end{array}$ & $\begin{array}{l}0.033 * * * \\
(0.003)\end{array}$ & $\begin{array}{l}0.040 * * * \\
(0.005)\end{array}$ & $\begin{array}{l}0.026^{* * * *} \\
(0.003)\end{array}$ & $\begin{array}{l}0.029 * * * \\
(0.002)\end{array}$ & \\
\hline $\begin{array}{l}\text { Ln(country GDP per } \\
\text { capita) }\end{array}$ & $\begin{array}{l}-0.007 * * \\
(0.003)\end{array}$ & $\begin{array}{l}0.004 * \\
(0.002)\end{array}$ & $\begin{array}{l}-0.004 \\
(0.004)\end{array}$ & $\begin{array}{l}0.002 \\
(0.002)\end{array}$ & $\begin{array}{l}0.001 \\
(0.002)\end{array}$ & $\begin{array}{l}0.017 \\
(0.016)\end{array}$ \\
\hline $\begin{array}{l}\text { Ln(region GDP per } \\
\text { capita) } \\
\text { Home-country and } \\
\text { host-region time- } \\
\text { variant control } \\
\text { variables }\end{array}$ & $\begin{array}{l}-0.023 * * * \\
(0.007)\end{array}$ & $\begin{array}{l}-0.013 * * * \\
(0.003)\end{array}$ & $\begin{array}{l}-0.017 * * * \\
(0.007)\end{array}$ & $\begin{array}{l}-0.014 * * * \\
(0.003)\end{array}$ & $\begin{array}{l}-0.015 * * * \\
(0.003)\end{array}$ & $\begin{array}{l}-0.009 \\
(0.026) \\
\text { Yes }\end{array}$ \\
\hline Constant & $\begin{array}{l}-0.008 \\
(0.089)\end{array}$ & $\begin{array}{l}0.073 \\
(0.045)\end{array}$ & $\begin{array}{l}-0.220 * * * \\
(0.070)\end{array}$ & $\begin{array}{l}-0.108^{*} \\
(0.064)\end{array}$ & $\begin{array}{l}-0.108^{*} \\
(0.056)\end{array}$ & $\begin{array}{l}-1.182 * * * \\
(0.354)\end{array}$ \\
\hline Year dummies & Yes & Yes & Yes & Yes & Yes & Yes \\
\hline Industry dummies & Yes & Yes & Yes & Yes & Yes & \\
\hline $\begin{array}{l}\text { Firm f.e. } \\
\mathrm{R}^{2}\end{array}$ & 0.050 & 0.048 & 0.068 & 0.041 & 0.043 & $\begin{array}{l}\text { Yes } \\
0.017\end{array}$ \\
\hline $\mathrm{N}$ & 10,010 & 47,641 & 9,902 & 47,749 & 57,651 & 55,465 \\
\hline
\end{tabular}

a) Standard errors are clustered on country-region. *, **, and *** denote significance at $10 \%, 5 \%$, and $1 \%$ respectively.

b) Home-country and host-region control variables in column 6 include country unemployment rate, country inflation, $\ln$ (country FDI per capita), $\ln$ (region crime), region unemployment rate, region inflation, $\ln$ (region FDI per capita), region higher-education graduates per capita, region R\&D personnel per capita, region capital investment per capita, and $\ln ($ region average wage). All variables are measured in year $\mathrm{t}$.

Sample: Model 6 has fewer observations due to differences in data availability for some country and region control variables. 
Table 6. Size of the Immigrant Community and Firm Cost and Revenue

\begin{tabular}{|c|c|c|c|c|}
\hline & (1) & (2) & (3) & (4) \\
\hline Variables & Cost & Revenue & Cost & Revenue \\
\hline Dependent variable & Cost/revenue & Revenue/assets & Cost/revenue & Revenue/assets \\
\hline Model & OLS & OLS & OLS & OLS \\
\hline Ln(immigrants) & $\begin{array}{l}-0.002 * * \\
(0.001)\end{array}$ & $\begin{array}{l}\text { 0.059*** } \\
(0.013)\end{array}$ & $\begin{array}{l}-\mathbf{- 0 . 0 0 1 5 *} \\
(0.0008)\end{array}$ & $\begin{array}{l}0.037 * * * \\
(0.012)\end{array}$ \\
\hline Ln(immigrants)* & & & 0.001 & -0.034 \\
\hline Entrepreneur & & & $(0.002)$ & $(0.033)$ \\
\hline Entrepreneur & & & $\begin{array}{l}-0.023^{*} \\
(0.013)\end{array}$ & $\begin{array}{l}0.719 * * * \\
(0.212)\end{array}$ \\
\hline Immigrant CEO & & & $\begin{array}{l}0.011 \\
(0.011)\end{array}$ & $\begin{array}{l}-0.158 \\
(0.102)\end{array}$ \\
\hline $\begin{array}{l}\text { Ln(immigrants)* } \\
\text { immigrant CEO }\end{array}$ & & & $\begin{array}{l}-0.0002 \\
(0.002)\end{array}$ & $\begin{array}{l}0.031 \\
(0.020)\end{array}$ \\
\hline Entrepreneur*immigrant & & & 0.004 & $-1.087 * * *$ \\
\hline CEO & & & $(0.021)$ & $(0.374)$ \\
\hline $\begin{array}{l}\text { Ln(immigrants)* } \\
\text { entrepreneur*immigrant } \\
\text { CEO }\end{array}$ & & & $\begin{array}{l}-0.002 \\
(0.003)\end{array}$ & $\begin{array}{l}0.155 * * * \\
(0.060)\end{array}$ \\
\hline Ln(assets) & $\begin{array}{l}-0.025 * * * \\
(0.003)\end{array}$ & $\begin{array}{l}-0.179 * * * \\
(0.022)\end{array}$ & $\begin{array}{l}-0.026 * * * \\
(0.003)\end{array}$ & $\begin{array}{l}-0.167 * * * \\
(0.022)\end{array}$ \\
\hline $\operatorname{Ln}(d e b t)$ & $\begin{array}{l}0.014 * * * \\
(0.003)\end{array}$ & $\begin{array}{l}0.132 * * * \\
(0.012)\end{array}$ & $\begin{array}{l}0.013 * * * \\
(0.003)\end{array}$ & $\begin{array}{l}0.129 * * * \\
(0.012)\end{array}$ \\
\hline Ln(age) & $\begin{array}{l}-0.007 * * \\
(0.002)\end{array}$ & $\begin{array}{l}0.083^{* *} \\
(0.033)\end{array}$ & $\begin{array}{l}-0.008 * * * \\
(0.002)\end{array}$ & $\begin{array}{l}0.105^{* * *} \\
(0.030)\end{array}$ \\
\hline Ln(country GDP per capita) & $\begin{array}{l}0.005 * * * \\
(0.002)\end{array}$ & $\begin{array}{l}-0.052 \\
(0.033)\end{array}$ & $\begin{array}{l}0.003 \\
(0.002)\end{array}$ & $\begin{array}{l}0.002 \\
(0.029)\end{array}$ \\
\hline Ln(region GDP per capita) & $\begin{array}{l}0.001 \\
(0.004)\end{array}$ & $\begin{array}{l}-0.198 * * * \\
(0.067)\end{array}$ & $\begin{array}{l}-0.0003 \\
(0.004)\end{array}$ & $\begin{array}{l}-0.163 * * * \\
(0.057)\end{array}$ \\
\hline Constant & $\begin{array}{l}1.100 * * * \\
(0.041)\end{array}$ & $\begin{array}{l}3.854 * * * \\
(0.787)\end{array}$ & $\begin{array}{l}1.135 * * * \\
(0.036)\end{array}$ & $\begin{array}{l}2.745^{* * * *} \\
(0.678)\end{array}$ \\
\hline Year dummies & Yes & Yes & Yes & Yes \\
\hline Industry dummies & Yes & Yes & Yes & Yes \\
\hline $\mathrm{R}^{2}$ & 0.069 & 0.085 & 0.069 & 0.089 \\
\hline $\mathrm{N}$ & 40,965 & 57,276 & 40,965 & 57,276 \\
\hline
\end{tabular}

a) Standard errors are clustered on country-region. *,**, and *** denote significance at $10 \%, 5 \%$, and $1 \%$ respectively.

Sample: Models 1 and 3 exclude firms with zero revenue and outliers. Models 2 and 4 exclude outliers. We have confirmed that our main results for OROA as a dependent variable in Table 3 hold if we make the same exclusions as in Table 6. 
Table 7. Variations of the Observed Effects for Foreign Entrepreneurs by the Type of the Region and the Type of the Firm ${ }^{\mathrm{a}}$

\begin{tabular}{|c|c|c|c|c|c|c|c|c|}
\hline & $(1)$ & $(2)$ & (3) & (4) & $(5)$ & (6) & $(7)$ & $(8)$ \\
\hline Variables & Soviet & $\begin{array}{l}\text { Non- } \\
\text { Soviet }\end{array}$ & Low-trust & High-trust & $\begin{array}{l}\text { Low } \\
\text { importance } \\
\text { of networks }\end{array}$ & $\begin{array}{l}\text { High } \\
\text { importance } \\
\text { of networks }\end{array}$ & $\begin{array}{l}\text { Retail trade } \\
\text { and services }\end{array}$ & $\begin{array}{l}\text { Manufacturi } \\
\text { ng }\end{array}$ \\
\hline Ln(immigrants) & $\begin{array}{l}-0.010 \\
(0.008)\end{array}$ & $\begin{array}{l}-0.002 \\
(0.003)\end{array}$ & $\begin{array}{l}-0.009 * * * \\
(0.003)\end{array}$ & $\begin{array}{l}0.001 \\
(0.003)\end{array}$ & $\begin{array}{l}-0.002 \\
(0.003)\end{array}$ & $\begin{array}{l}-0.005 \\
(0.004)\end{array}$ & $\begin{array}{l}-0.012 * * * \\
(0.004)\end{array}$ & $\begin{array}{l}0.003 \\
(0.005)\end{array}$ \\
\hline Immigrant CEO & $\begin{array}{l}-0.084 \\
(0.096)\end{array}$ & $\begin{array}{l}-0.087 * * * \\
(0.033)\end{array}$ & $\begin{array}{l}-0.118 * * * \\
(0.039)\end{array}$ & $\begin{array}{l}-0.051 \\
(0.033)\end{array}$ & $\begin{array}{l}-0.039 \\
(0.033)\end{array}$ & $\begin{array}{l}-0.110 \text { *** } \\
(0.040)\end{array}$ & $\begin{array}{l}-0.187 * * * \\
(0.075)\end{array}$ & $\begin{array}{l}-0.027 \\
(0.042)\end{array}$ \\
\hline $\begin{array}{l}\text { Ln(immigrants)*immigrant } \\
\text { CEO }\end{array}$ & $\begin{array}{l}0.012 \\
(0.011)\end{array}$ & $\begin{array}{l}0.015 * * * \\
(\mathbf{0 . 0 0 6 )}\end{array}$ & $\begin{array}{l}\mathbf{0 . 0 2 2} * * * \\
(\mathbf{0 . 0 0 5 )}\end{array}$ & $\begin{array}{l}0.009 \\
(0.005)\end{array}$ & $\begin{array}{l}0.006 \\
(0.005)\end{array}$ & $\begin{array}{l}\mathbf{0 . 0 2 0} * * * \\
(\mathbf{0 . 0 0 5 )}\end{array}$ & $\begin{array}{l}\mathbf{0 . 0 3 0} * * * \\
(\mathbf{0 . 0 1 1 )}\end{array}$ & $\begin{array}{l}-0.001 \\
(0.007)\end{array}$ \\
\hline $\begin{array}{l}\chi^{2} \text { value for differences between } \\
\text { samples }\end{array}$ & \multicolumn{2}{|c|}{$\chi^{2}=0.07$} & \multicolumn{2}{|c|}{$\chi^{2}=3.17 *$} & \multicolumn{2}{|c|}{$\chi^{2}=3.48^{*}$} & \multicolumn{2}{|c|}{$\chi^{2}=5.20 * *$} \\
\hline $\operatorname{Ln}$ (assets) & $\begin{array}{l}0.025 * * * \\
(0.007)\end{array}$ & $\begin{array}{l}0.035 * * * \\
(0.005)\end{array}$ & $\begin{array}{l}0.029 * * * \\
(0.009)\end{array}$ & $\begin{array}{l}0.034 * * * \\
(0.005)\end{array}$ & $\begin{array}{l}0.026 * * * \\
(0.004)\end{array}$ & $\begin{array}{l}0.046 * * * \\
(0.007)\end{array}$ & $\begin{array}{l}0.037 * * * \\
(0.008)\end{array}$ & $\begin{array}{l}0.028 * * * \\
(0.007)\end{array}$ \\
\hline $\operatorname{Ln}($ debt $)$ & $\begin{array}{l}-0.011 * * * \\
(0.003)\end{array}$ & $\begin{array}{l}-0.015 * * * \\
(0.003)\end{array}$ & $\begin{array}{l}-0.013 * * * \\
(0.005)\end{array}$ & $\begin{array}{l}-0.014 * * * \\
(0.002)\end{array}$ & $\begin{array}{l}-0.010 * * * \\
(0.002)\end{array}$ & $\begin{array}{l}-0.022 * * * \\
(0.004)\end{array}$ & $\begin{array}{l}-0.016 * * * \\
(0.004)\end{array}$ & $\begin{array}{l}-0.015 * * * \\
(0.004)\end{array}$ \\
\hline Ln(country GDP per capita) & $\begin{array}{l}-0.011 \\
(0.001)\end{array}$ & $\begin{array}{l}-0.008^{* *} \\
(0.004)\end{array}$ & $\begin{array}{l}-0.017 * \\
(0.010)\end{array}$ & $\begin{array}{l}-0.005 \\
(0.003)\end{array}$ & $\begin{array}{l}-0.004 \\
(0.003)\end{array}$ & $\begin{array}{l}-0.015 * * \\
(0.007)\end{array}$ & $\begin{array}{l}-0.015^{* *} \\
(0.007)\end{array}$ & $\begin{array}{l}-0.003 \\
(0.008)\end{array}$ \\
\hline Ln(region GDP per capita) & $\begin{array}{l}-0.040^{* * * *} \\
(0.014)\end{array}$ & $\begin{array}{l}-0.020^{* *} \\
(0.009)\end{array}$ & $\begin{array}{l}-0.088 * * * \\
(0.027)\end{array}$ & $\begin{array}{l}-0.017 * \\
(0.009)\end{array}$ & $\begin{array}{l}0.0003 \\
(0.013)\end{array}$ & $\begin{array}{l}-0.013 \\
(0.019)\end{array}$ & $\begin{array}{l}-0.050 * * * \\
(0.018)\end{array}$ & $\begin{array}{l}-0.012 \\
(0.015)\end{array}$ \\
\hline Constant & $\begin{array}{l}0.099 \\
(0.196)\end{array}$ & $\begin{array}{l}-0.107 \\
(0.096)\end{array}$ & $\begin{array}{l}0.717 \text { *** } \\
(0.219)\end{array}$ & $\begin{array}{l}-0.126 \\
(0.094)\end{array}$ & $\begin{array}{l}-0.191 \\
(0.134)\end{array}$ & $\begin{array}{l}0.163 \\
(0.173)\end{array}$ & & \\
\hline Year dummies & Yes & Yes & Yes & Yes & Yes & Yes & Yes & Yes \\
\hline Industry dummies & Yes & Yes & Yes & Yes & Yes & Yes & Yes & Yes \\
\hline $\mathrm{R}^{2}$ & 0.076 & 0.054 & 0.123 & 0.048 & 0.040 & 0.077 & 0.067 & 0.074 \\
\hline $\mathrm{N}$ & 1,881 & 8,129 & 1,369 & 7,970 & 5,276 & 4,063 & 2,585 & 1,222 \\
\hline
\end{tabular}

a) Standard errors are clustered on country-region. *,**, and *** denote significance at $10 \%, 5 \%$, and $1 \%$ respectively. Variation in sample size across specifications is due to differences in data availability for the variables of interest. 
Table 8. Robustness Checks ${ }^{\mathrm{a}}$

\begin{tabular}{|c|c|c|c|c|c|c|}
\hline & $(1)$ & (2) & (3) & $(4)$ & $(5)$ & $(6)$ \\
\hline Variables & $\begin{array}{l}\text { Controlling } \\
\text { for the stock } \\
\text { of the home- } \\
\text { country firms } \\
\text { in the region }\end{array}$ & $\begin{array}{l}\text { Majority- } \\
\text { owned and } \\
\text { wholly owned } \\
\text { foreign firms }\end{array}$ & $\begin{array}{l}<50 \\
\text { employees }\end{array}$ & $\begin{array}{l}\geq 50 \\
\text { employees }\end{array}$ & $\begin{array}{l}\text { Immigrant } \\
\text { share }\end{array}$ & $\begin{array}{l}\text { Immigrant } \\
\text { flow }\end{array}$ \\
\hline Dependent variable & OROA & OROA & OROA & OROA & OROA & OROA \\
\hline Model & OLS & OLS & OLS & OLS & OLS & OLS \\
\hline Ln(immigrants) & $\begin{array}{l}\mathbf{0 . 0 0 5 * * *} \\
(\mathbf{0 . 0 0 1 )}\end{array}$ & $\begin{array}{l}\mathbf{0 . 0 0 4} * * * \\
(\mathbf{0 . 0 0 1 )}\end{array}$ & $\begin{array}{l}\mathbf{0 . 0 0 3} * * * \\
(\mathbf{0 . 0 0 1 )}\end{array}$ & $\begin{array}{l}\mathbf{0 . 0 0 6}^{* * * *} \\
(\mathbf{0 . 0 0 1 )}\end{array}$ & & \\
\hline $\begin{array}{l}\text { Ln(stock of home-country } \\
\text { firms) }\end{array}$ & $\begin{array}{l}-0.002 \\
(0.002)\end{array}$ & & & & & \\
\hline $\begin{array}{l}\text { Ln(immigrants)* } \\
100 \text { percent foreign }\end{array}$ & & $\begin{array}{l}\mathbf{0 . 0 0 1} \\
(0.001)\end{array}$ & & & & \\
\hline 100 percent foreign & & $\begin{array}{l}0.003 \\
(0.006)\end{array}$ & & & & \\
\hline Ln(immigrant share) & & & & & $\begin{array}{l}0.059 * * \\
(0.030)\end{array}$ & \\
\hline Ln(immigrant flow) & & & & & & $\begin{array}{l}\mathbf{0 . 0 0 5} * * * \\
(0.001)\end{array}$ \\
\hline $\operatorname{Ln}$ (asset) & $\begin{array}{l}0.016 * * * \\
(0.002)\end{array}$ & $\begin{array}{l}0.016 * * * \\
(0.002)\end{array}$ & $\begin{array}{l}0.010 * * * \\
(0.001)\end{array}$ & $\begin{array}{l}0.028 * * * \\
(0.005)\end{array}$ & $\begin{array}{l}0.016 * * * \\
(0.002)\end{array}$ & $\begin{array}{l}0.016 * * * \\
(0.002)\end{array}$ \\
\hline $\operatorname{Ln}(d e b t)$ & $\begin{array}{l}-0.005 * * * \\
(0.001)\end{array}$ & $\begin{array}{l}-0.005 * * * \\
(0.001)\end{array}$ & $\begin{array}{l}-0.005 * * * \\
(0.001)\end{array}$ & $\begin{array}{l}-0.018 * * * \\
(0.005)\end{array}$ & $\begin{array}{l}-0.005 * * * \\
(0.001)\end{array}$ & $\begin{array}{l}-0.005 * * * \\
(0.001)\end{array}$ \\
\hline Ln(age) & $\begin{array}{l}0.027 * * * \\
(0.003)\end{array}$ & $\begin{array}{l}0.027 * * * \\
(0.003)\end{array}$ & $\begin{array}{l}0.021 * * * \\
(0.004)\end{array}$ & $\begin{array}{l}0.023 * * * \\
(0.004)\end{array}$ & $\begin{array}{l}0.028 * * * \\
(0.003)\end{array}$ & $\begin{array}{l}0.027 * * * \\
(0.003)\end{array}$ \\
\hline Ln(country GDP per capita) & $\begin{array}{l}-0.003 \\
(0.002)\end{array}$ & $\begin{array}{l}-0.003^{*} \\
(0.002)\end{array}$ & $\begin{array}{l}-0.008 * * * \\
(0.002)\end{array}$ & $\begin{array}{l}0.008^{* *} \\
(0.003)\end{array}$ & $\begin{array}{l}-0.004 \\
(0.002)\end{array}$ & $\begin{array}{l}-0.004^{*} \\
(0.002)\end{array}$ \\
\hline Ln(region GDP per capita) & $\begin{array}{l}-0.014 * * \\
(0.006)\end{array}$ & $\begin{array}{l}-0.018 * * * \\
(0.004)\end{array}$ & $\begin{array}{l}-0.020 * * * \\
(0.004)\end{array}$ & $\begin{array}{l}-0.005 \\
(0.004)\end{array}$ & $\begin{array}{l}-0.011 * * \\
(0.004)\end{array}$ & $\begin{array}{l}-0.016^{* * * *} \\
(0.004)\end{array}$ \\
\hline Constant & $\begin{array}{l}-0.051 \\
(0.077)\end{array}$ & $\begin{array}{l}-0.019 \\
(0.063)\end{array}$ & $\begin{array}{l}0.124 * * \\
(0.051)\end{array}$ & $\begin{array}{l}-0.106^{*} \\
(0.055)\end{array}$ & $\begin{array}{l}-0.064 \\
(0.068)\end{array}$ & $\begin{array}{l}-0.022 \\
(0.064)\end{array}$ \\
\hline Year dummies & Yes & Yes & Yes & Yes & Yes & Yes \\
\hline Industry dummies & Yes & Yes & Yes & Yes & Yes & Yes \\
\hline $\mathrm{R}^{2}$ & 0.040 & 0.040 & 0.021 & 0.063 & 0.039 & 0.039 \\
\hline $\mathrm{N}$ & 57,651 & 57,651 & 35,926 & 15,946 & 57,651 & 57,651 \\
\hline
\end{tabular}

a) Standard errors are clustered on country-region. *,**, and *** denote significance at $10 \%, 5 \%$, and $1 \%$ respectively.

Sample: Models 3 and 4 have slightly fewer observations because employment data were unavailable for some firm-years. 
Table 9. Importing and Non-importing Firms ${ }^{\mathrm{a}}$

\begin{tabular}{|c|c|c|c|c|}
\hline & $(1)$ & $(2)$ & (3) & (4) \\
\hline Variables & $\begin{array}{l}\text { Importing } \\
\text { behavior as a } \\
\text { proxy for } \\
\text { product type }\end{array}$ & $\begin{array}{l}\text { Controlling } \\
\text { for } \\
\text { importing } \\
\text { behavior }\end{array}$ & $\begin{array}{l}100 \% \text { foreign } \\
\text { ownership as } \\
\text { a proxy for } \\
\text { product type }\end{array}$ & $\begin{array}{l}\text { Controlling } \\
\text { for } 100 \% \\
\text { foreign } \\
\text { ownership }\end{array}$ \\
\hline Dependent variable & OROA & OROA & OROA & OROS \\
\hline Model & OLS & OLS & OLS & OLS \\
\hline Ln(immigrants) & $\begin{array}{l}0.001 \\
(0.001)\end{array}$ & $\begin{array}{l}0.001 \\
(0.001)\end{array}$ & $\begin{array}{l}0.004 * * * \\
(0.001)\end{array}$ & $\begin{array}{l}0.004 * * * \\
(0.001)\end{array}$ \\
\hline Ln(immigrants)*entrepreneur & $\begin{array}{l}0.002 \\
(0.004)\end{array}$ & $\begin{array}{l}-0.003 \\
(0.004)\end{array}$ & $\begin{array}{l}-0.001 \\
(0.003)\end{array}$ & $\begin{array}{l}-0.004 \\
(0.003)\end{array}$ \\
\hline Entrepreneur & $\begin{array}{l}0.044^{*} \\
(0.024)\end{array}$ & $\begin{array}{l}0.068^{* *} \\
(0.026)\end{array}$ & $\begin{array}{l}0.025 \\
(0.016)\end{array}$ & $\begin{array}{l}0.040 * * \\
(0.018)\end{array}$ \\
\hline Immigrant CEO & & $\begin{array}{l}0.009 \\
(0.009)\end{array}$ & & $\begin{array}{l}0.011 \\
(0.010)\end{array}$ \\
\hline Ln(immigrants)*immigrant CEO & & $\begin{array}{l}-0.002 \\
(0.002)\end{array}$ & & $\begin{array}{l}-0.001 \\
(0.002)\end{array}$ \\
\hline Entrepreneur*immigrant CEO & & $\begin{array}{l}-0.082 * * \\
(0.033)\end{array}$ & & $\begin{array}{l}-0.087 * * * \\
(0.032)\end{array}$ \\
\hline Ln(immigrant)*entrepreneur*immigrant CEO & & $\begin{array}{l}0.014 * * * \\
(0.005)\end{array}$ & & $\begin{array}{l}0.013 * * * \\
(0.005)\end{array}$ \\
\hline Entrepreneur*importing & $\begin{array}{l}-0.018 \\
(0.026)\end{array}$ & $\begin{array}{l}-0.020 \\
(0.025)\end{array}$ & & \\
\hline Ln(immigrants)*entrepreneur*importing & $\begin{array}{l}-0.005 \\
(0.004)\end{array}$ & $\begin{array}{l}-0.005 \\
(0.004)\end{array}$ & & \\
\hline Entrepreneur*100 percent foreign & & & $\begin{array}{l}0.018 \\
(0.027)\end{array}$ & $\begin{array}{l}0.032 \\
(0.026)\end{array}$ \\
\hline Ln(immigrants)*entrepreneur*100 percent foreign & & & $\begin{array}{l}0.001 \\
(0.004)\end{array}$ & $\begin{array}{l}-0.002 \\
(0.004)\end{array}$ \\
\hline Ln(immigrants)*importing & $\begin{array}{l}0.005^{* * * *} \\
(0.001)\end{array}$ & $\begin{array}{l}0.005 * * * \\
(0.001)\end{array}$ & & \\
\hline Importing & $\begin{array}{l}0.010 \\
(0.007)\end{array}$ & $\begin{array}{l}0.009 \\
(0.007)\end{array}$ & & \\
\hline $\operatorname{Ln}($ immigrants $) * 100$ percent foreign & & & $\begin{array}{l}-0.0002 \\
(0.001)\end{array}$ & $\begin{array}{l}-0.0002 \\
(0.001)\end{array}$ \\
\hline 100 percent foreign & & & $\begin{array}{l}0.003 \\
(0.005)\end{array}$ & $\begin{array}{l}0.003 \\
(0.005)\end{array}$ \\
\hline Control variables & \multicolumn{4}{|c|}{$\begin{array}{l}\operatorname{Ln}(\text { assets }), \ln (\text { debt }), \ln (\text { age }), \ln (\text { country GDP per capita), } \\
\ln (\text { region GDP per capita) }\end{array}$} \\
\hline Constant & $\begin{array}{l}0.035 \\
(0.101)\end{array}$ & $\begin{array}{l}0.036 \\
(0.099)\end{array}$ & $\begin{array}{l}-0.105^{*} \\
(0.057)\end{array}$ & $\begin{array}{l}-0.106^{*} \\
(0.055)\end{array}$ \\
\hline Year dummies & Yes & Yes & Yes & Yes \\
\hline Industry dummies & Yes & Yes & Yes & Yes \\
\hline $\mathrm{R}^{2}$ & 0.045 & 0.045 & 0.042 & 0.043 \\
\hline $\mathrm{N}$ & 57,113 & 57,113 & 57,651 & 57,651 \\
\hline
\end{tabular}

a) Standard errors are clustered on country-region. *,**, and *** denote significance at $10 \%, 5 \%$, and $1 \%$ respectively.

Sample: Models 1 and 2 include firms with available importing information. 